\title{
Medium optimization for biomass production of three peat moss (Sphagnum L.) species using fractional factorial design and response surface methodology
}

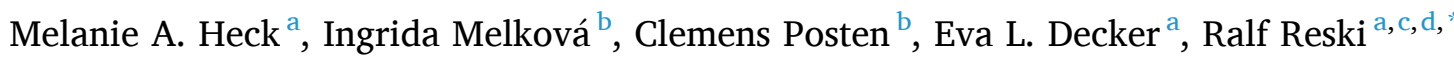 \\ ${ }^{a}$ Plant Biotechnology, Faculty of Biology, University of Freiburg, Freiburg, Germany \\ ${ }^{\mathrm{b}}$ Institute of Process Engineering in Life Sciences III Bioprocess Engineering, Karlsruhe Institute of Technology (KIT), Karlsruhe, Germany \\ ${ }^{\mathrm{c}}$ CIBSS - Centre for Integrative Biological Signalling Studies, University of Freiburg, Freiburg, Germany \\ ${ }^{\mathrm{d}}$ Cluster of Excellence livMatS @ FIT - Freiburg Center for Interactive Materials and Bioinspired Technologies, University of Freiburg, Freiburg, Germany
}

\section{A R T I C L E I N F O}

\section{Keywords:}

Design of experiments

Medium optimization

Peat moss

Photobioreactor

Sphagnum farming

\begin{abstract}
A B S T R A C T
Peat moss (Sphagnum) biomass is a promising bioresource of renewable material to substitute peat in growing media. For sustainable production on a large scale, the productivity of Sphagnum mosses has to be increased by optimizing culture conditions. Optimization was achieved using experimental design to determine concentrations of eight factors leading to highest biomass yield. We improved an established Sphagnum medium by reducing the concentrations of $\mathrm{NH}_{4} \mathrm{NO}_{3}, \mathrm{KH}_{2} \mathrm{PO}_{4}, \mathrm{KCl}, \mathrm{MgSO}_{4}, \mathrm{Ca}\left(\mathrm{NO}_{3}\right)_{2}, \mathrm{FeSO}_{4}$ and a microelement solution up to $50 \%$. Together with sucrose concentrations of $16 \mathrm{~g} \mathrm{~L}^{-1}$ for Sphagnum fuscum and $20 \mathrm{~g} \mathrm{~L}^{-1}$ for Sphagnum palustre and Sphagnum squarrosum, moss productivities were enhanced for all tested species in shake flasks. Further upscaling to $5 \mathrm{~L}$ photobioreactors increased the biomass yield: $15 \mathrm{~g}$ freshweight resulted in about $630 \mathrm{~g}$ for $S$. fuscum (50-fold), $580 \mathrm{~g}$ for $S$. palustre (40-fold) and $400 \mathrm{~g}$ for $S$. squarrosum (25-fold) in 24 days.
\end{abstract}

\section{Introduction}

Peat mosses (Sphagnum spec.) are among the oldest land plants and are rapidly gaining interest in basic and applied research. Their applications range from traditional medicine like wound dressing (Sabovljević et al., 2016) to biotechnological applications such as biomonitoring of air pollutants (Aboal et al., 2020; Capozzi et al., 2017; Di Palma et al., 2019). Due to their high water retention capability, they are a preferred substrate for the horticultural industry (Burnett et al., 2016). In addition, they are important for the global climate as a major constituent of peatlands, which are the largest terrestrial long-term biological carbon storage (Joosten et al., 2016). Peatlands cover around $3 \%$ of the global land area and store around a quarter of the world's soil carbon (Turetsky et al., 2015). Therefore, peat mosses have a large impact on carbon cycling, which makes them a suitable plant model in carbon cycling studies (Weston et al., 2018). The availability of the first genome sequences of two Sphagnum species (Sphagnum fallax v1.1 and Sphagnum magellanicum v1.1, DOE-JGI, http://phytozom e-next.jgi.doe.gov/) will further extend the research possibilities and scientific impact, as has been observed for Physcomitrella patens, the first fully sequenced moss (Rensing et al., 2008).

To further provide this climate regulation, peatlands have to be preserved (Joosten et al., 2016). But on the long term, the peatland is getting destroyed for peat extraction or agricultural use. Drainage leads to release of the stored carbon, which accounts for $32 \%$ of global cropland greenhouse gas (GHG) emission (Carlson et al., 2017). However, Sphagnum biomass can be produced in an environmentally friendly and sustainable land use option on rewetted peatlands, an application named Sphagnum farming (Gaudig et al., 2014). Rewetting drained peatlands reduces GHG emisions and simultaneously produces a renewable alternative to fossil peat, which is the best-quality horticultural growing medium so far (Gaudig et al., 2018). The suitability for their use in these growing media have tested positively for various Sphagnum species, e.g. S. fuscum, S. palustre or S. squarrosum, depending on the cultivated plant and proportion of biomass in the culture substrate (Gaudig et al., 2018).

Large-scale implementation of Sphagnum farming is limited by the lack of peat moss founder material. So far, there is no supply for Sphagnum due to the scarcity and the conservation status of Sphagnum mosses (e.g. by the European Council Habitats Directive (92/43/EEC)).

\footnotetext{
* Corresponding author at: Plant Biotechnology, Schaenzlestr. 1, 79104 Freiburg, Germany.

E-mail address: ralf.reski@biologie.uni-freiburg.de (R. Reski).
} 
In addition, peat moss collected in natural habitats may include undesired Sphagnum species or vascular plants which could limit its use (Gaudig et al., 2018). A promising method for obtaining the required founder material is based on vegetative regeneration of Sphagnum under controlled conditions, because peat mosses regenerate from many parts of the shoot like capitula, branches and stems, but not from leaves (Poschlod and Pfadenhauer, 1989; Sobotka, 2015). While Sphagnum propagates slowly under natural conditions, in-vitro cultivation could accelerate peat moss growth.

An important step towards large-scale production of founder material was the development of an axenic laboratory scale Sphagnum photobioreactor. Cultivation of Sphagnum palustre yielded in a 30-fold biomass increase within four weeks (Beike et al., 2015). This accelerated the production of founder material drastically compared to the 2.5 -fold biomass increase per year in the field and in glasshouse experiments (Gaudig et al., 2014; Beike et al., 2015). Another important step was the establishment of axenic in-vitro cultures of 19 Sphagnum species with a selection of productive clones to achieve maximum yields (Heck et al., 2021), which was based on a medium developed for $S$. palustre by Beike et al. (2015). However, Heck et al. (2021) noted that this medium was not optimal for all of the tested species. The basic cultivation techniques are established, but the cultivation process requires optimization for each Sphagnum species.

Therefore, three species, favorable bioresource candidates for both Sphagnum farming and horticultural growing media (Gaudig et al., 2018), were selected for optimization of the medium content. Under investigation were $S$. fuscum, $S$. squarrosum and $S$. palustre as one of the most promising peat mosses, because of their high productivity on different Sphagnum farming sites (Gaudig et al., 2014). They belong to different sections and natural habitats: $S$. fuscum (section Acutifolia) is an ombrotrophic (rain-fed) species and grows predominantly in nutrientpoor oligotrophic and mesotrophic mires; $S$. palustre (section Sphagnum) grows in a wide range of mesotrophic peatlands containing intermediate levels of nutrients and is absent only from strongly acidic locations; S. squarrosum (section Squarrosa) grows predominantly in mesotrophic to slightly eutrophic areas (Daniels and Eddy, 1990).

Here, we report on the optimized media compositions for biomass production, for axenic in-vitro cultivation of the three species $S$. fuscum, $S$. palustre and $S$. squarrosum in small scale obtained by the screening and optimization of eight factors: sucrose, $\mathrm{NH}_{4} \mathrm{NO}_{3}, \mathrm{KH}_{2} \mathrm{PO}_{4}, \mathrm{KCl}, \mathrm{MgSO}_{4}$, $\mathrm{Ca}\left(\mathrm{NO}_{3}\right)_{2}, \mathrm{FeSO}_{4}$ and micro elements (ME). Design experiments helps to determine the most important input factors, understand the interaction between factors and identify the factor settings leading to optimized output responses (Fukuda et al., 2018). It can be divided into two steps: 1) screening designs, like fractional factorial design at two levels, where many factors are studied to identify the significant ones and 2) optimization designs, like the central composite as one of the most widely used designs, where the factors are further examined to determine the best conditions (Candioti et al., 2014; Singh et al., 2017; Maina et al., 2019).

The results from an optimized $5 \mathrm{~L}$ laboratory scale photobioreactor are presented for all three Sphagnum species, supported by tracked $\mathrm{pH}$ value and nutrient concentration analysis. This served for a better understanding of the nutrient demand of the tested Sphagnum species with respect to the different biomass production among the species. Under consideration of the nutrient dynamics, the batch process as strategy of the large scale peat moss biomass production was tested and showed the limitation in Sphagnum growth.

\section{Materials and methods}

\subsection{In-vitro cultivation}

The peat mosses for this study, each derived from a single spore, are described in Heck et al. (2021), and are vailable from the International Moss Stock Center (https://www.moss-stock-center.org) under their respective IMSC accession number. For suspension cultures of the clones
S. fuscum 1.1 (IMSC \#41158), S. palustre 12a (IMSC \#40068) and S. squarrosum 5.2 (IMSC \#41193), gametophores were disrupted with forceps in a laminar flow cabinet (LaminAir, Heraeus, Hanau, Germany) and transferred to 500 or $1000 \mathrm{~mL}$ Erlenmeyer flasks filled with 200 or $500 \mathrm{~mL}$ liquid Sphagnum medium, respectively. Standard Sphagnum medium consists of Knop medium $\left(1.84 \mathrm{mM} \mathrm{KH}_{2} \mathrm{PO}_{4}, 3.35 \mathrm{mM} \mathrm{KCl}\right.$, $1.01 \mathrm{mM} \mathrm{MgSO}_{4} \cdot 7 \mathrm{H}_{2} \mathrm{O}, 4.24 \mathrm{mM} \mathrm{Ca}\left(\mathrm{NO}_{3}\right)_{2} \cdot 4 \mathrm{H}_{2} \mathrm{O}, 45 \mu \mathrm{M} \mathrm{FeSO}_{4} \cdot 7$ $\mathrm{H}_{2} \mathrm{O}$ ) according to Reski and Abel (1985). This is supplemented with microelements (ME; $50 \mu \mathrm{M} \mathrm{H}_{3} \mathrm{BO}_{3}, 50 \mu \mathrm{M} \mathrm{MnSO}_{4} \cdot \mathrm{H}_{2} \mathrm{O}, 15 \mu \mathrm{M} \mathrm{ZnSO}_{4} \cdot 7$ $\mathrm{H}_{2} \mathrm{O}, 2.5 \mu \mathrm{M} \mathrm{KJ}, 500 \mathrm{nM} \mathrm{Na}_{2} \mathrm{MoO}_{4} \cdot 2 \mathrm{H}_{2} \mathrm{O}, 50 \mathrm{nM} \mathrm{CuSO}_{4} \cdot 5 \mathrm{H}_{2} \mathrm{O}, 50 \mathrm{nM}$ $\left.\mathrm{Co}\left(\mathrm{NO}_{3}\right)_{2} \cdot 6 \mathrm{H}_{2} \mathrm{O}\right)$ according to Schween et al. (2003). This is then supplemented with $2 \%$ sucrose and $1.25 \mathrm{mM} \mathrm{NH}_{4} \mathrm{NO}_{3}$ with an adjusted $\mathrm{pH}$ of 4.8 before autoclaving according to Beike et al. (2015). The flasks were closed with Silicosen ${ }^{\circledR}$ silicone sponge plugs (Hirschmann Laborgeräte $\mathrm{GmbH} \&$ Co. KG, Eberstadt, Germany) to allow gas exchange, and placed on a rotary shaker at $120 \mathrm{rpm}$ (B. Braun Biotech International $\mathrm{GmbH}$, Melsungen, Germany). Standard cultivation conditions were: climate chamber at a temperature of $22{ }^{\circ} \mathrm{C}$ under a photoperiod regime of $16 / 8 \mathrm{~h}$ (light/dark) with a light intensity of $70 \pm$ $5 \mu \mathrm{mol} \mathrm{m}{ }^{-2} \mathrm{~s}^{-1}$ provided from above by fluorescent tubes (Master TL-D Super 80, Philips, Amsterdam, The Netherlands). Average measurements of light intensity were done manually with a planar quantum sensor (Li-Cor 250, Li-Cor Biosciences GmbH, Bad Homburg, Germany).

To check for putative contaminations, either medium or moss material were transferred to plates containing three different solid media, Knop ME, LB, and TSA, respectively. For detection of contamination, Knop ME medium was supplemented with $1 \%$ glucose and $12 \mathrm{~g} \mathrm{~L}^{-1}$ Purified Agar (Oxoid Ltd. UK) with an adjusted $\mathrm{pH}$ of 5.8 before autoclaving. LB medium contained $10 \mathrm{~g} \mathrm{~L}^{-1}$ Bacto Tryptone (Becton, Dickinson \& Co., NJ, USA), $10 \mathrm{~g} \mathrm{~L}^{-1} \mathrm{NaCl}, 5 \mathrm{~g} \mathrm{~L}^{-1}$ Bacto Yeast Extract (Becton, Dickinson \& Co.) and $15 \mathrm{~g} \mathrm{~L}^{-1}$ Bacto Agar (Becton, Dickinson \& Co.) with an adjusted $\mathrm{pH}$ of 7.0 before autoclaving. Tryptic Soy Agar (TSA) contained $15 \mathrm{~g} \mathrm{~L}^{-1}$ peptone from casein, $5 \mathrm{~g} \mathrm{~L}^{-1}$ soy peptone, $5 \mathrm{~g}$ $\mathrm{L}^{-1} \mathrm{NaCl}, 1 \%$ glucose and $12 \mathrm{~g} \mathrm{~L}^{-1}$ purified agar (Oxoid Limited) with an adjusted $\mathrm{pH}$ of 7.5 before autoclaving. These control plates were sealed with Parafilm and incubated for four weeks at room temperature. A culture was considered axenic if no contamination on the plates occurred within that time.

\subsection{Bioreactor cultivation}

For scaling-up the cultivation process of $S$. fuscum, $S$. palustre and $S$. squarrosum ( $n=3$ for optimized medium, $n=2$ for standard Sphagnum medium), glass tank photobioreactors with $5.4 \mathrm{~L}$ working volume were used (Applikon Biotechnology, Schiedam, The Netherlands). A bioreactor was inoculated with a two-week-old preculture grown in Erlenmeyer flasks. For inoculum, $15 \mathrm{~g}$ of peat moss were weighed after removing excess medium by filtering for $1 \mathrm{~min}$ using a Steritop filter (Millipore Corporation, Billerica, MA, USA) and a vacuum pump (Vacuubrand MZ 2C, Vacuubrand GmbH and Co, Wertheim, Germany), disrupted with forceps and filled in a flask containing $500 \mathrm{~mL}$ Sphagnum medium and cultivated under standard cultivation conditions. The whole content of the flask was transferred with $5 \mathrm{~L}$ of optimized medium to the photobioreactor. The reactor was illuminated with 12 neutral white $(4000 \mathrm{~K})$ LED stripes (MaxLine70, Lumitronix, Hechingen, Germany) placed around the reactor at $2 \mathrm{~cm}$ distance. The light intensity, measured behind the reactor glas wall, was increased stepwise from initially $150 \mu \mathrm{mol} \mathrm{m} \mathrm{m}^{-2} \mathrm{~s}^{-1}$ to $300 \mu \mathrm{mol} \mathrm{m} \mathrm{m}^{-2} \mathrm{~s}^{-1}$ at day 3 up to $500 \mu \mathrm{mol} \mathrm{m} \mathrm{m}^{-2} \mathrm{~s}^{-1}$ at day 7 with a day/night cycle of $20 / 4 \mathrm{~h}$ and aeration of $0.3 \mathrm{vvm}$ with $2 \% \mathrm{CO}_{2}$-enriched air, which was passed trough a water bottle before entering the bioreactor. The bioreactor was equipped with a marine impeller placed $22 \mathrm{~cm}$ above the bottom. The cultures of $S$. palustre and $S$. squarrosum were stirred constantly with 100 rpm starting at day 17 to ensure that the moss plants did not aggregate. During the cultivation of $S$. fuscum, the bioreactor was not stirred, as no clumping of the mosses occurred. The $\mathrm{pH}$ was not adjusted, but was 
tracked during cultivation with an internal $\mathrm{pH}$ electrode (Applikon Biotechnology). The biomass increase was documented photographically directly after inoculation and at 3, 7, 10, 13, 15, 17, 20, 22 and 24 days. At the same time points $40 \mathrm{~mL}$ of medium were withdrawn from the bioreactor to measure nutrient consumption (see 2.3). After 24 days all material of the bioreactor was harvested and the biomass, fresh weights (see 2.4), and dry weights (see 2.5 ) were determined.

\subsection{Nutrient measurement}

Prior to nutrient measurement all samples were passed through 0.45 $\mu \mathrm{m}$ PVDF filters (Rotalibo, Carl Roth, Karlsruhe, Germany). Inorganic ions were determined as triplicates by an ion chromatograph (822 Compact IC plus, Methrom, Herisau, Switzerland) equipped with a Metrosep A Supp 5150/4 column (Metrohm) and a guard column A Supp $4 / 5$ Guard 4.0 (Metrohm) to determine anion concentrations $\left(\mathrm{Cl}^{-}, \mathrm{NO}_{3}^{-}\right.$, $\mathrm{PO}_{4}^{3-}, \mathrm{SO}_{4}^{2-}$ ). The eluent for the anion measurement was an aqueous solution of $3.2 \mathrm{mM} \mathrm{Na}_{2} \mathrm{CO}_{3}, 1.0 \mathrm{mM} \mathrm{NaHCO}_{3}$ and $12.5 \%(v / \mathrm{v})$ acetonitrile. To determine cation concentrations as triplicates $\left(\mathrm{Na}^{+}, \mathrm{NH}_{4}^{+}, \mathrm{K}^{+}\right.$, $\mathrm{Ca}^{2+}, \mathrm{Mg}^{2+}$ ), Metrosep C4 150/4.0 columns (Metrohm) and Metrosep $\mathrm{C} 4 \mathrm{~S}$-Gurad columns (Metrohm) with an eluent of $1.7 \mathrm{mM} \mathrm{HNO}_{3}$ and 0.7 $\mathrm{mM}$ 2,6-pyridinedicarboxylic acid were used. All solutions were prepared with ultra pure water (resistance $16 \mathrm{M} \Omega$; Maxima, ELGA LabWater, Celle, Germany). Filtrated medium samples were diluted and injected automatically by an autosample unit (885 Professional sample Processor, Methrom) and analyzed with a conductivity detector (Metrohm). This system was controlled and data processed using MagIC Net 2.3 software (Metrohm).

The analysis of glucose, fructose and sucrose was carried out as triplicates with the Sucrose/D-Fructose/D-Glucose Assay Kit (Megazyme, Bray, Ireland) according to the manufacturer's protocol. For use in 96 well microplates (Greiner Bio One, Kremsmünster, Austria) the assay volumes were reduced to $10 \%$. A sucrose and D-glucose/D-fructose standard curve was performed on each microplate and the results were calculated from the calibration curve. The absorbance was measured at $340 \mathrm{~nm}$ with a microplate reader (CLARIOstar, BMG Labtech, Ortenberg, Germany).

\subsection{Fresh weight determination}

Fresh weight was measured by filtering the total content of the bioreactor with a Büchner funnel and generating a vacuum for $1 \mathrm{~min}$ by closing the funnel with a plug sealed with Parafilm. The amount of the peat moss biomass retained on the filter was weighed on a scale (E12000 S, Sartorius, Göttingen, Germany).

\subsection{Dry weight determination}

To measure dry weights from flask cultures, total biomass was harvested by filtering with a Büchner funnel and a vacuum pump. The moss material was transferred to pre-dried $\left(0.5 \mathrm{~h}\right.$ at $\left.105{ }^{\circ} \mathrm{C}\right)$ aluminum weighing pans (Köhler Technische Produkte, Neulußheim, Germany) and dried for $2 \mathrm{~h}$ at $105^{\circ} \mathrm{C}$ in a forced air oven (Ehret GmbH Life Science Solutions, Freiburg, Germany).

The moss material from the bioreactor (after fresh weight determination) was filled in a miracloth bag. Due to higher biomass amounts, the drying time was increased to $10 \mathrm{~h}$ and the drying temperature was reduced to $80^{\circ} \mathrm{C}$ in order to prevent scorching the biomass. The dried moss material in the weighing pan/miracloth bag was weighed with an accuracy scale (CPA 3245, Sartorius).

\subsection{Experimental design for medium optimization}

In the context of medium optimization, Design of Experiments (DOE) is a powerful statistical tool that gained an increasing interest over traditional methods like one factor at time (OFAT) (Duraković, 2017).
Changing one factor, while keeping the others constant, is a timeconsuming process, as it requires a high number of experiments without determining the existence of interactions between individual factors. DOE overcomes these limitations by providing better results with fewer experiments (Fukuda et al., 2018). The optimization of the medium components for biomass increase was carried out for $S$. fuscum, S. palustre and $S$. squarrosum. The influence and significance of the media components, including the eight factors sucrose, $\mathrm{NH}_{4} \mathrm{NO}_{3}, \mathrm{KH}_{2} \mathrm{PO}_{4}, \mathrm{KCl}$, $\mathrm{MgSO}_{4}, \mathrm{Ca}\left(\mathrm{NO}_{3}\right)_{2}, \mathrm{ME}$ and $\mathrm{FeSO}_{4}$, on the biomass yield (produced dry weight) were determined and optimized using Design-Expert ${ }^{\circledR}$ software (Version 11.1.2.0, Stat-Ease, Minneapolis, MN, USA) based on the analysis of variance (ANOVA).

\subsubsection{Identification of important components}

Screening was done using a two-level factorial design $\left(2^{\mathrm{k}-\mathrm{p}}\right)$, with the number of factors $(\mathrm{k})$ and the number of generators (p), where low versus high factor settings were compared resulting in a linear model. To detect non-linearity, center points have to be added, located at the exact mid-point of all factor settings. Eight factors $(\mathrm{k}=8)$, which represent the main components of the standard Sphagnum medium, were selected. Each of the factors was set at three levels: low $(-1)$, high $(+1)$ and the center point inbetween (0). Sucrose range from 3 to $20 \mathrm{~g} \mathrm{~L}^{-1}$ and the other factors between $50 \%$ and $100 \%$ of the standard Sphagnum medium for S. fuscum and S. squarrosum and between $10 \%$ and $100 \%$ for S. palustre (Table 1). In the fractional factorial design, $\mathrm{k}$ factors were screened based on just $2^{\mathrm{k}-4}$ experiments resulting in 16 runs conducted as duplicates and four replicates of the center point. In total, 36 experiments were performed in random order. The flasks were filled with 200 $\mathrm{mL}$ of the respective medium and inoculated with $250 \mathrm{mg}$ of moss material each. Before weighing, the disrupted gametophores with an accuracy scale (E12000 S, Sartorius) in laminar flow benches, the gametophores were filtered for $1 \mathrm{~min}$ using a Steritop filter and a vacuum pump. After cultivation for four weeks under standard cultivation conditions, dry weights were determined and the significant factors identified.

The results were analyzed by selecting the factors with the highest $\mathrm{t}$ values. Effects below the t-value limit were only selected to support hierarchy. This means that a factor was selected even if it has a nonsignificant effect on the response, but interaction with another factor significantly influences the response. In this design, all interaction effects are aliased, also known as confounded, as the number of experiments in the fractional factorial design is smaller than the number of different treatment combinations. For example, the effects of AB, CE, DH and FG are aliased and the effect of one of these combinations cannot be distinguished from the others.

The selected factorial model was checked using ANOVA. To trust the model, the following terms were checked: the $p$-value of the model term $\leq 0.05$ reveals that the model is significant; the $p$-values of the selected

\section{Table 1}

The factors and their levels for two-level factorial design as first screening of the optimized media composition towards biomass production of $S$. fuscum, $S$. squarrosum and $S$. palustre. Code level represents a change in concentration of each factor: -1 reduced concentration, +1 elevated concentration, 0 inbetween (center point).

\begin{tabular}{|c|c|c|c|c|c|c|c|}
\hline \multirow[t]{2}{*}{ Symbols } & \multirow[t]{2}{*}{ Factor } & \multicolumn{6}{|c|}{ Code level } \\
\hline & & -1 & 0 & +1 & -1 & 0 & +1 \\
\hline & & \multicolumn{3}{|c|}{ S. fuscum/S. squarrosum } & \multicolumn{3}{|c|}{ S. palustre } \\
\hline A & Sucrose $\left(\mathrm{g} \mathrm{L}^{-1}\right)$ & 3 & 11.5 & 20 & 3 & 11.5 & 20 \\
\hline B & $\mathrm{NH}_{4} \mathrm{NO}_{3}(\mathrm{mM})$ & 0.63 & 0.94 & 1.25 & 0.5 & 0.875 & 1.25 \\
\hline $\mathrm{C}$ & $\mathrm{KH}_{2} \mathrm{PO}_{4}(\mathrm{mM})$ & 0.92 & 1.38 & 1.84 & 0.18 & 1.01 & 1.84 \\
\hline $\mathrm{D}$ & $\mathrm{KCl}(\mathrm{mM})$ & 1.68 & 2.52 & 3.35 & 0.34 & 1.845 & 3.35 \\
\hline $\mathrm{E}$ & $\mathrm{MgSO}_{4}(\mathrm{mM})$ & 0.51 & 0.76 & 1.01 & 0.1 & 0.555 & 1.01 \\
\hline $\mathrm{F}$ & $\mathrm{Ca}\left(\mathrm{NO}_{3}\right)_{2}(\mathrm{mM})$ & 2.12 & 3.18 & 4.24 & 0.42 & 2.33 & 4.24 \\
\hline G & ME (\%) & 50 & 75 & 100 & 10 & 55 & 100 \\
\hline $\mathrm{H}$ & $\mathrm{FeSO}_{4}(\mu \mathrm{M})$ & 22.5 & 33.8 & 45 & 4.5 & 24.75 & 45 \\
\hline
\end{tabular}


factors $\leq 0.05$ indicates that the factors are significant and have an effect on the response, the p-values of the selected factors $>0.1$ indicates that the factors are not significant, but have to be selected as they are important for the interaction effects together with another factor. The lack of fit p-value $>0.05$ indicates that the lack of fit is not significant, as a significant lack of fit indicates the model does not fit the data within the observed replicate variation and a more complex model has to be considered. $\mathrm{R}^{2}$, adjusted $\mathrm{R}^{2}$ and predicted $\mathrm{R}^{2}=1$ indicates perfect adaptation and prediction of the model, therefore the higher these values the better the model. The difference of $\mathrm{R}^{2}$ adj. and $\mathrm{R}^{2}$ pred. should be smaller than 0.2 , otherwise the model is not correct. The adequate precision, a signal-to-noise ratio, should be $>4$ to guarantee that the signal is strong enough and can be used for optimization. If curvature appears significant, a quadratic or higher order model is required to model the relationship between the factors and the response with a response surface design (Design Expert, Stat-Ease).

\subsubsection{Optimization of screened components}

On the basis of the results obtained from the factorial design in the first screening, the media composition was further optimized in a second experiment using a response surface methodology (RSM) (Bezerra et al., 2008). Five factors were detected to enhance the biomass growth during the screening experiments. The three remaining factors were kept at a constant level, $50 \%$ of the concentration of the standard Sphagnum medium: $0.92 \mathrm{mM} \mathrm{KH}_{2} \mathrm{PO}_{4}, 1.68 \mathrm{mM} \mathrm{KCl}, 0.51 \mathrm{mM} \mathrm{MgSO}_{4}, 50 \% \mathrm{ME}$ and $22.5 \mu \mathrm{M} \mathrm{FeSO}_{4}$. A factorial, central composite design (CCD) for five factors was used with replicates at the center points. Each factor was used at five coded levels: $-\infty,-1,0,+1,+\infty$ (Table 2). Code levels $\mp 1$ represent the factorial points as 50 and $100 \%$ of the concentration of the standard Sphagnum medium and as 3 and $20 \mathrm{~g} \mathrm{~L}^{-1}$ of sucrose, 0 the center points and $-/+\infty$ represents the axial points on the axis of the design space with a defined distance $(\alpha)$ set at 1.49535 coded units from the design center. All linear and interaction terms can be calculated by the facorial points. The axial points can be used for estimation of the quadratic terms.

\section{Table 2}

The factors and their levels for central composite design used for media optimization towards biomass production of $S$. fuscum, $S$. palustre and $S$. squarrosum. The first column gives the Sphagnum species with their individual medium components without previous statistical significance $(50 \%$ of the standard Sphagnum medium). Code levels $-/+\infty$ represents the axial points, $-/+1$ the factorial points as reduced and elevated concentration and 0 the center point of each factor. The chemical formulas of hydrated salts are expressed without water molecules.

\begin{tabular}{|c|c|c|c|c|c|c|}
\hline \multirow[t]{2}{*}{ Symbols } & \multirow[t]{2}{*}{ Factor } & \multicolumn{5}{|c|}{ Code levels } \\
\hline & & $-\infty$ & -1 & 0 & +1 & $+\infty$ \\
\hline \multicolumn{7}{|l|}{ S. fuscum } \\
\hline $\mathrm{A}$ & Sucrose $\left(\mathrm{g} \mathrm{L}^{-1}\right)$ & 1.28 & 5 & 12.5 & 20 & 23.72 \\
\hline B & $\mathrm{NH}_{4} \mathrm{NO}_{3}(\mathrm{mM})$ & 0.47 & 0.63 & 0.94 & 1.25 & 1.40 \\
\hline $\mathrm{C}$ & $\mathrm{KH}_{2} \mathrm{PO}_{4}(\mathrm{mM})$ & 0.69 & 0.92 & 1.38 & 1.84 & 2.07 \\
\hline $\mathrm{D}$ & $\mathrm{Ca}\left(\mathrm{NO}_{3}\right)_{2}(\mathrm{mM})$ & 1.59 & 2.12 & 3.18 & 4.24 & 4.77 \\
\hline $\mathrm{E}$ & ME (\%) & 37.6 & 50 & 75 & 100 & 123.8 \\
\hline \multicolumn{7}{|c|}{ with $1.68 \mathrm{mM} \mathrm{KCl}, 0.51 \mathrm{mM} \mathrm{MgSO}_{4}, 22.5 \mu \mathrm{M} \mathrm{FeSO}{ }_{4}$} \\
\hline \multicolumn{7}{|c|}{ S. palustre } \\
\hline A & Sucrose $\left(\mathrm{g} \mathrm{L}^{-1}\right)$ & 1.28 & 5 & 12.5 & 20 & 23.72 \\
\hline B & $\mathrm{NH}_{4} \mathrm{NO}_{3}(\mathrm{mM})$ & 0.47 & 0.63 & 0.94 & 1.25 & 1.40 \\
\hline $\mathrm{C}$ & $\mathrm{KH}_{2} \mathrm{PO}_{4}(\mathrm{mM})$ & 0.69 & 0.92 & 1.38 & 1.84 & 2.07 \\
\hline $\mathrm{D}$ & $\mathrm{MgSO}_{4}(\mathrm{mM})$ & 0.38 & 0.51 & 0.76 & 1.01 & 1.14 \\
\hline $\mathrm{E}$ & $\mathrm{Ca}\left(\mathrm{NO}_{3}\right)_{2}(\mathrm{mM})$ & 1.59 & 2.12 & 3.18 & 4.24 & 4.77 \\
\hline \multicolumn{7}{|c|}{ with $1.68 \mathrm{mM} \mathrm{KCl}, 50 \% \mathrm{ME}, 22.5 \mu \mathrm{M} \mathrm{FeSO}{ }_{4}$} \\
\hline \multicolumn{7}{|c|}{ S. squarrosum } \\
\hline A & Sucrose $\left(\mathrm{g} \mathrm{L}^{-1}\right)$ & 1.28 & 5 & 12.5 & 20 & 23.72 \\
\hline B & $\mathrm{NH}_{4} \mathrm{NO}_{3}(\mathrm{mM})$ & 0.47 & 0.63 & 0.94 & 1.25 & 1.40 \\
\hline $\mathrm{C}$ & $\mathrm{Ca}\left(\mathrm{NO}_{3}\right)_{2}(\mathrm{mM})$ & 1.59 & 2.12 & 3.18 & 4.24 & 4.77 \\
\hline $\mathrm{D}$ & ME (\%) & 37.6 & 50 & 75 & 100 & 112.4 \\
\hline $\mathrm{E}$ & $\mathrm{FeSO}_{4}(\mu \mathrm{M})$ & 16.9 & 22.5 & 33.8 & 45 & 50.6 \\
\hline
\end{tabular}

The CCD contained a total of 50 experiments that included 32 trials for factorial design, 10 trials for axial points (two for each variable) and eight trials for replication of the center points. The flasks were filled with $200 \mathrm{~mL}$ of the required medium, inoculated with $250 \mathrm{mg}$ of moss material and cultivated for four weeks ( $S$. fuscum and $S$. palustre) under standard cultivation conditions. The cultivation of $S$. squarrosum was prolonged for one week, because of the weak growth performance compared to the other two species. Due to space limitations on the rotary shakers, the flasks were not shaken in week one and three and shaken continuously in week two and four ( $S$. fuscum and $S$. palustre), and additionally in week five ( $S$. squarrosum). The biomass yield was determined at the end of cultivation by measuring the dry weight, and the model was analyzed.

The highest order polynomial model was selected where the sequential $p$ value $\leq 0.05$ is significant, the lack of fit $p$-value $>0.05$ is not significant, adjusted $\mathrm{R}^{2}$ and predicted $\mathrm{R}^{2}$ are as high as possible, and the model is not aliased. The significant factors had to be selected by backwards elimination of non-significant factors with a p value $>0.1$ or a linear effect has to be selected to support hierarchy. The selected model including the selected factors was checked using ANOVA. Transformation was applied to meet statistical assumptions by analysing residuals and a new model has to be selected and checked again as described before (Design Expert, Stat-Ease). The best fitting model was a reduced quadratic response surface including inverse square root transformation for $S$. fuscum, whilst the data for $S$. palustre and $S$. squarrosum did not require transformations to fit statistical assumptions.

\subsubsection{Validation of the optimized media composition determined by the model}

To validate the optimized media composition, according to the abovementioned applied model, we conducted tests similar to the previous CCD experiments. Shake flasks experiments $(n=3$, with exception of the predicted optimized media of $S$. squarrosum $n=2$ ) were carried out and the biomass yield between the medium composition of the center points of the CCD and the predicted optimized media concentration were compared.

\subsection{Statistical analysis}

The statistical software package Design-Expert ${ }^{\circledR}$ (Stat-Ease, 11.1.2.0, Minneapolis, USA) was used for regression analysis of experimental data and to plot response surface. ANOVA was used to estimate the statistical parameters.

\section{Results and discussion}

\subsection{Screening of important medium components for biomass production}

The standard Sphagnum medium was established by Beike et al. (2015) with regard to $S$. palustre productivity, and tested for four other Sphagnum species. However, this medium was not suitable for optimized biomass production for the 19 Sphagnum species tested by Heck et al. (2021). Nevertheless, it is a good basis for peat moss cultivation because it comprises all components necessary for moss growth: sucrose, nitrogen (ammonia, nitrate), macroelements $\left(\mathrm{Ca}^{2-}, \mathrm{Fe}^{3+}, \mathrm{K}^{+}, \mathrm{PO}_{4}^{3-}, \mathrm{SO}_{4}^{2-}\right)$ and micro elements (ME).

The used experimental matrix including 16 trials for the 8 different variables (nutrients of Sphagnum medium) and the dry weight as response for each setup is shown in Table S1 for $S$. fuscum, Table S2 for $S$. palustre and Table S3 for $S$. squarrosum, sorted by the standard order (Std). The highest tested concentration corresponds to the standard Sphagnum medium and $10 \%$ of this medium to the lowest concentration adjusted for $S$. palustre. This yielded in a biomass ranging between 28.6 and $100.6 \mathrm{mg}$ DW with a maximum yield of $95.6 \pm 5.1 \mathrm{mg} \mathrm{DW} \mathrm{l}^{-1}$ for Std 31 and 32, representing the standard Sphagnum medium (Table S2). 
To reduce the wide range of biomass yield, the range between the factors could be narrowed. As the highest $S$. palustre biomass was gained with the highest tested concentration of all factors, the lower value of all factors was set to $50 \%$ for the screening experiments of $S$. fuscum and S. squarrosum. S. fuscum grew between 33.4 and $65.6 \mathrm{mg} \mathrm{DW} \mathrm{L}^{-1}$, where the standard Sphagnum medium yielded the highest biomass (Table S1, Std 31, 32). The biomass of $S$. squarrosum yielded between 10.1 and $45.6 \mathrm{mg} \mathrm{DW} \mathrm{L}{ }^{-1}$. Compared to the other two species, the standard Sphagnum medium resulted in an only moderate biomass increase for this species, whereas the reduction of $\mathrm{NH}_{4} \mathrm{NO}_{3}, \mathrm{KCl}, \mathrm{MgSO}_{4}$ and $\mathrm{ME}$ yielded the highest biomass (Table S3).

The ANOVA results are presented in Table 3, where all three models are significant with a non-significant lack of fit, indicating no reason to doubt the fitness of the model. Out of the eight variables studied, the biomass of $S$. fuscum was positively influenced by an increase in the concentration of sucrose, $\mathrm{NH}_{4} \mathrm{NO}_{3}, \mathrm{KH}_{2} \mathrm{PO}_{4}, \mathrm{Ca}\left(\mathrm{NO}_{3}\right)_{2}$ and ME (Table 3). The biomass of $S$. palustre was positively influenced by an increase in the concentration of sucrose, $\mathrm{NH}_{4} \mathrm{NO}_{3}, \mathrm{KH}_{2} \mathrm{PO}_{4}, \mathrm{MgSO}_{4}$ and $\mathrm{Ca}\left(\mathrm{NO}_{3}\right)_{2}$ (Table 3 ). The biomass of $S$. squarrosum was positively influenced by an increase in the concentration of sucrose and $\mathrm{Ca}\left(\mathrm{NO}_{3}\right)_{2}$, and by a decrease in the concentration of $\mathrm{NH}_{4} \mathrm{NO}_{3}, \mathrm{ME}$ and $\mathrm{FeSO}_{4}$ (Table 3). With fractional factorial designs some limitations can occur for the estimation of the main and interaction effects, because some are estimated together (Candioti et al., 2014). Another limitation relies on the fact that they have only two levels for each input factor, resulting in a linear model (Fukuda et al., 2018). To accept the linearity of the model, center points have to be added at the exact mid-point of all factor settings to evaluate curvature and identify significant second-order effects (Bezerra et al., 2008). Especially as the significant curvature test of $S$. palustre and $S$. squarrosum indicates non-linearity of the model (Table 3), a more complex model has to be used to identify the optimized media concentration.

In this two-level factorial design, the highest $S$. palustre biomass yield was achieved with the standard Sphagnum medium with $2 \%$ sucrose. The second highest $S$. fuscum biomass yield was also achieved with that medium. In contrast, the productivity of $S$. squarrosum was on an average with that medium. This correlates with the findings of Heck et al. (2021), who reported that the nutrient composition of the standard Sphagnum medium is suboptimal for some Sphagnum species and has to be improved further.

The productivity of all three Sphagnum species was positively influenced by sucrose. These growth-promoting effects of sugar have also been found in previous in-vitro cultivation studies (Beike et al., 2015; Rudolph et al., 1988; Simola, 1969).

The nitrogen sources $\mathrm{NH}_{4} \mathrm{NO}_{3}$ and $\mathrm{Ca}\left(\mathrm{NO}_{3}\right)_{2}$ also positively influence the productivity of all three Sphagnum species. This is in accordance with the positive effect of $1.25 \mathrm{mM} \mathrm{NH} \mathrm{NO}_{3}$ on the growth of $S$. nemoreum (Simola, 1975), and combined with sucrose on the growth of $S$. palustre (Beike et al., 2015). The effect of $\mathrm{Ca}\left(\mathrm{NO}_{3}\right)_{2}$ cannot be attributed to one of the ions due to ion confounding. Ion confounding occurs through the use of salts, because changing the concentration of a single cation or anion results in a simultaneous change in the associated co-ion (Niedz and Evens, 2006). Varying $\mathrm{Ca}\left(\mathrm{NO}_{3}\right)_{2}$ varies both the $\mathrm{Ca}^{2+}$ and $\mathrm{NO}_{3}^{-}$ions simultaneously. Any change in the output may be due to the varied ion concentration of $\mathrm{Ca}^{2+}$ or $\mathrm{NO}_{3}^{-}$or the interaction between $\mathrm{Ca}^{2+}$ and $\mathrm{NO}_{3}^{-}$. The use of salts instead of ions as a factor impaired the detailed understanding of the metabolism as the ion-specific effects are not obvious. The treatment of the components as a salt and not as ions as one factor was neccesary to keep the number of trials small. This reduced the number of factors to eight and with it the number of experiments. Nevertheless, the optimization of the media components was the main focus of this study and the growth-influencing factors were identified.

\subsection{Optimization of the screened medium}

Once the screening process identified the relevant factors, a more
Table 3

Analysis of variance (ANOVA) generated by Design Expert software (Stat-Ease, 11.1.2.0) for the two-level factorial design used as first screening for the optimized media composition of $S$. fuscum, S. palustre and $S$. squarrosum in relation to biomass production. Sum of squares, degree of freedom (df), mean square, Fvalue and p-value. R-squared $\left(R^{2}\right)$, adjusted R-squared $\left(R^{2}\right.$ adj), predicted $R$ squared $\left(\mathrm{R}^{2}\right.$ pred) and Adequate Precision (Adeq Precision). For not defined source letters please refer to Table 1 .

\begin{tabular}{|c|c|c|c|c|c|c|}
\hline Source & $\begin{array}{l}\text { Sum of } \\
\text { squares }\end{array}$ & df & $\begin{array}{l}\text { Mean } \\
\text { square }\end{array}$ & $\begin{array}{l}\text { F- } \\
\text { value }\end{array}$ & $\mathrm{p}$-value & \\
\hline \multicolumn{7}{|l|}{ S. fuscum } \\
\hline Model & 1618.01 & 6 & 269.67 & 8.86 & $<0.0001$ & Significan \\
\hline A-Sucrose & 1155.48 & 1 & 1155.48 & 37.97 & $<0.0001$ & \\
\hline B- $\mathrm{NH}_{4} \mathrm{NO}_{3}$ & 83.95 & 1 & 83.95 & 2.76 & 0.1075 & \\
\hline $\mathrm{C}-\mathrm{KH}_{2} \mathrm{PO}_{4}$ & 100.71 & 1 & 100.71 & 3.31 & 0.0792 & \\
\hline F-Ca $\left(\mathrm{NO}_{3}\right)_{2}$ & 27.32 & 1 & 27.32 & 0.8980 & 0.3511 & \\
\hline G-ME & 113.21 & 1 & 113.21 & 3.72 & 0.0636 & \\
\hline $\begin{array}{c}\mathrm{AF} \text { or BG } \\
\text { CH DE }\end{array}$ & 137.32 & 1 & 137.32 & 4.51 & 0.0423 & \\
\hline Residual & 882.40 & 29 & 30.43 & & & \\
\hline Lack of Fit & 170.61 & 10 & 17.06 & 0.4554 & 0.8985 & $\begin{array}{l}\text { Not } \\
\text { significant }\end{array}$ \\
\hline Pure Error & 711.79 & 19 & 37.46 & & & \\
\hline \multicolumn{7}{|c|}{$\mathrm{R}^{2}=0.6741, \mathrm{R}^{2}$ adj $=0.5741, \mathrm{R}^{2}$ pred $=0.4630$, Adeq Precision $=10.0378$} \\
\hline \multicolumn{7}{|l|}{ S. palustre } \\
\hline Model & 6393.94 & 10 & 639.39 & 31.61 & $<0.0001$ & Significan \\
\hline A-Sucrose & 3088.00 & 1 & 3088.00 & 152.67 & $<0.0001$ & \\
\hline B- $\mathrm{NH}_{4} \mathrm{NO}_{3}$ & 468.87 & 1 & 468.87 & 23.18 & $<0.0001$ & \\
\hline $\mathrm{C}-\mathrm{KH}_{2} \mathrm{PO}_{4}$ & 59.11 & 1 & 59.11 & 2.92 & 0.1003 & \\
\hline$E-\mathrm{MgSO}_{4}$ & 382.75 & 1 & 382.75 & 18.92 & 0.0002 & \\
\hline $\mathrm{F}-\mathrm{Ca}\left(\mathrm{NO}_{3}\right)_{2}$ & 181.59 & 1 & 181.59 & 8.98 & 0.0063 & \\
\hline $\begin{array}{c}\mathrm{AB} \text { or } \mathrm{CE} \\
\mathrm{DH} F \mathrm{FG}\end{array}$ & 924.61 & 1 & 924.61 & 45.71 & $<0.0001$ & \\
\hline $\begin{array}{r}\mathrm{AF} \text { or BG } \\
\mathrm{CH} \mathrm{DE}\end{array}$ & 568.43 & 1 & 568.43 & 28.10 & $<0.0001$ & \\
\hline $\begin{array}{r}\mathrm{BC} \text { or } \mathrm{AE} \\
\mathrm{DF} \mathrm{GH}\end{array}$ & 157.13 & 1 & 157.13 & 7.77 & 0.0102 & \\
\hline $\begin{array}{c}\text { BE or AC } \\
\text { DG FH }\end{array}$ & 442.90 & 1 & 442.90 & 21.90 & $<0.0001$ & \\
\hline $\begin{array}{r}\mathrm{EF} \text { or } \mathrm{AD} \\
\mathrm{BH} C \mathrm{G}\end{array}$ & 120.55 & 1 & 120.55 & 5.96 & 0.0224 & \\
\hline Curvature & 2436.54 & 1 & 2436.54 & 120.46 & $<0.0001$ & \\
\hline Residual & 485.44 & 24 & 20.23 & & & \\
\hline Lack of Fit & 191.22 & 5 & 38.24 & 2.47 & 0.0694 & $\begin{array}{l}\text { Not } \\
\text { significant }\end{array}$ \\
\hline Pure Error & 294.22 & 19 & 15.49 & & & \\
\hline \multicolumn{7}{|c|}{$\mathrm{R}^{2}=0.9294, \mathrm{R}^{2}$ adj $=0.9000, \mathrm{R}^{2}$ pred $=0.8372$, Adeq Precision $=21.9775$} \\
\hline \multicolumn{7}{|l|}{ S. squarrosum } \\
\hline Model & 1348.03 & 7 & 192.58 & 6.23 & 0.0002 & Significan \\
\hline A-Sucrose & 120.16 & 1 & 120.16 & 3.89 & 0.0590 & \\
\hline B- $\mathrm{NH}_{4} \mathrm{NO}_{3}$ & 305.11 & 1 & 305.11 & 9.86 & 0.0041 & \\
\hline $\mathrm{F}-\mathrm{Ca}\left(\mathrm{NO}_{3}\right)_{2}$ & 222.45 & 1 & 222.45 & 7.19 & 0.0123 & \\
\hline G-ME & 407.34 & 1 & 407.34 & 13.17 & 0.0012 & \\
\hline $\mathrm{H}-\mathrm{FeSO}_{4}$ & 16.57 & 1 & 16.57 & 0.5359 & 0.4705 & \\
\hline $\begin{array}{c}\mathrm{AF} \text { or BG } \\
\mathrm{CH} \mathrm{DE}\end{array}$ & 140.16 & 1 & 140.16 & 4.53 & 0.0426 & \\
\hline $\begin{array}{c}\mathrm{AH} \text { or BD } \\
\text { CF EG }\end{array}$ & 136.25 & 1 & 136.25 & 4.41 & 0.0453 & \\
\hline Curvature & 467.85 & 1 & 467.85 & 15.13 & 0.0006 & \\
\hline Residual & 835.11 & 27 & 30.93 & & & \\
\hline Lack of Fit & 330.98 & 8 & 41.37 & 1.56 & 0.2027 & $\begin{array}{l}\text { Not } \\
\text { significant }\end{array}$ \\
\hline Pure Error & 504.13 & 19 & 26.53 & & & \\
\hline \multicolumn{7}{|c|}{$\mathrm{R}^{2}=0.6175, \mathrm{R}^{2}$ adj $=0.5183, \mathrm{R}^{2}$ pred $=0.3200$, Adeq Precision $=9.5611$} \\
\hline
\end{tabular}

complex model is required to optimize them (Fukuda et al., 2018).

The used experimental design and results obtained for biomass production of the CCD are shown in Table S4 for $S$. fuscum, Table S5 for $S$. palustre and Table $\mathrm{S} 6$ for $S$. squarrosum. In the case of $S$. fuscum, sucrose and $\mathrm{Ca}\left(\mathrm{NO}_{3}\right)_{2}$ as well as the quadratic effects of sucrose, $\mathrm{NH}_{4} \mathrm{NO}_{3}$ and $\mathrm{KH}_{2} \mathrm{PO}_{4}$ had a positive effect on biomass production. The productivity of $S$. palustre was positively influenced by linear effects of sucrose and $\mathrm{NH}_{4} \mathrm{NO}_{3}$ as well as by the quadratic effects of $\mathrm{NH}_{4} \mathrm{NO}_{3}, \mathrm{MgSO}_{4}$ and $\mathrm{Ca}\left(\mathrm{NO}_{3}\right)_{2}$ (see Table 3). Sucrose and $\mathrm{NH}_{4} \mathrm{NO}_{3}$ had the same positive 
effect on the biomass production of $S$. squarrosum as well as interaction effects of sucrose with $\mathrm{NH}_{4} \mathrm{NO}_{3}$ and $\mathrm{ME}$ with $\mathrm{FeSO}_{4}$, and quadratic effects of sucrose (Table 4).

To investigate the interaction between two variables on the biomass production, three-dimensional response surfaces were plotted on the basis of the final model, whereby the remaining variables were kept constant at their optimum level. The interaction between $\mathrm{NH}_{4} \mathrm{NO}_{3}$ and sucrose shows the nonlinear effect of these factors on the biomass production of $S$. fuscum, S. palustre and $S$. squarrosum (Fig. 1). The optimal concentration may lie outside the ranges initially chosen for $S$. palustre and $S$. squarrosum, as the highest predicted biomass is at the border. However, in previous studies, increased sucrose concentrations of $5 \%$ or higher negatively affected peat moss productivity (Beike et al., 2015; Simola, 1969).

In the CCD experiments, $S$. squarrosum yielded the highest biomass with Std 2 (Table S6), which is in agreement with the model prediction that the optimized medium composition has a high concentration of sucrose and low concentrations of the remaining nutrients (Table 5). S. fuscum and S. palustre yielded the highest biomass in Std 47 (Table S4) and Std 46 (Table S5), both representing one center point. This corresponds to the model prediction, where the optimal nutrient concentration is similar to the medium composition at the center points of S. fuscum and S. palustre (Table 5).

\subsection{Validation of the optimized medium in flasks}

To verify the obtained optimized media concentrations with regard to improved biomass yields, validation experiments were conducted. All three validation experiments yielded higher biomasses by using the optimized media concentration. For $S$. fuscum, a biomass of $491.6 \pm$ $24.7 \mathrm{mg}$ DW was obtained by using the optimized concentrations, compared to $403.4 \pm 5.8 \mathrm{mg}$ DW by using the concentrations of the center point, which yielded the highest biomass during the optimization experiment. The prediction could be confirmed and the model seems to be adequate despite the significant lack of fit (Table 4). The optimized media of $S$. palustre yielded a maximum biomass of $473.6 \pm 10.9 \mathrm{mg}$ DW compared to $402.0 \pm 24.8 \mathrm{mg}$ DW by using the concentrations of the center point representing the best productivity during the optimization experiment. $S$. squarrosum yielded $707.6 \pm 5.3 \mathrm{mg}$ DW in the validation experiment with the predicted optimized media, whereas the same media composition yielded only $356.8 \mathrm{mg}$ DW during the CCD (Table S6, Std 2).

This variance in biomass production is most likely a consequence of heterogenous starting material. The inocula of all three species were treated in the same way, but the preculture could differ concerning length of the gametophores and number of capitula, because the moss material was disrupted manually with forceps. Vegetative growth of peat mosses is possible from several parts of the shoot, like capitula, fascicles, branches and stems (Poschlod and Pfadenhauer, 1989). Green

Table 4

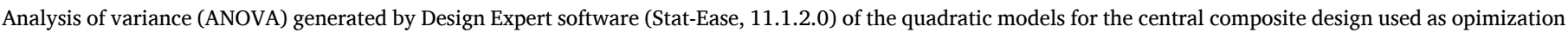

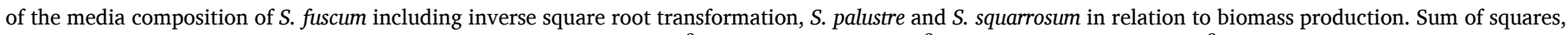

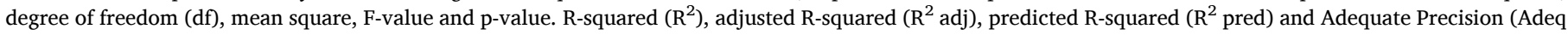
Precision).

\begin{tabular}{|c|c|c|c|c|c|c|}
\hline Source & Sum of squares & df & Mean square & F-value & p-value & \\
\hline \multicolumn{7}{|l|}{ S. fuscum } \\
\hline Model & 0.0011 & 7 & 0.0002 & 9.28 & $<0.0001$ & Significant \\
\hline A-Sucrose & 0.0004 & 1 & 0.0004 & 22.45 & $<0.0001$ & \\
\hline B- $\mathrm{NH}_{4} \mathrm{NO}_{3}$ & 0.0000 & 1 & 0.0000 & 0.8903 & 0.3508 & \\
\hline $\mathrm{C}-\mathrm{KH}_{2} \mathrm{PO}_{4}$ & 0.0000 & 1 & 0.0000 & 1.48 & 0.2303 & \\
\hline D-Ca $\left(\mathrm{NO}_{3}\right)_{2}$ & 0.0001 & 1 & 0.0001 & 3.27 & 0.0776 & \\
\hline $\mathrm{A}^{2}$ & 0.0002 & 1 & 0.0002 & 11.84 & 0.0013 & \\
\hline $\mathrm{B}^{2}$ & 0.0001 & 1 & 0.0001 & 3.64 & 0.0631 & \\
\hline$C^{2}$ & 0.0001 & 1 & 0.0001 & 3.27 & 0.0776 & \\
\hline Residual & 0.0007 & 42 & 0.0000 & & & \\
\hline Lack of Fit & 0.0007 & 35 & 0.0000 & 6.41 & 0.0080 & Significant \\
\hline Pure Error & 0.0000 & 7 & $3.018 \mathrm{E}-06$ & & & \\
\hline \multicolumn{7}{|c|}{$\mathrm{R}^{2}=0.6072, \mathrm{R}^{2}$ adj $=0.5418, \mathrm{R}^{2}$ pred $=0.3505$, Adeq Precision $=9.7669$} \\
\hline \multicolumn{7}{|l|}{ S. palustre } \\
\hline Model & $1.046 \mathrm{E}+05$ & 7 & $14,936.59$ & 7.95 & $<0.0001$ & Significant \\
\hline A-Sucrose & $33,776.79$ & 1 & $33,776.79$ & 17.97 & 0.0001 & \\
\hline B- $\mathrm{NH}_{4} \mathrm{NO}_{3}$ & 6072.73 & 1 & 6072.73 & 3.23 & 0.0794 & \\
\hline $\mathrm{D}-\mathrm{MgSO}_{4}$ & 579.41 & 1 & 579.41 & 0.3083 & 0.5817 & \\
\hline $\mathrm{E}-\mathrm{Ca}\left(\mathrm{NO}_{3}\right)_{2}$ & 216.48 & 1 & 216.48 & 0.1152 & 0.7360 & \\
\hline $\mathrm{B}^{2}$ & 6204.97 & 1 & 6204.97 & 3.30 & 0.0764 & \\
\hline $\mathrm{D}^{2}$ & 6419.33 & 1 & 6419.33 & 3.42 & 0.0716 & \\
\hline $\mathrm{E}^{2}$ & $19,632.16$ & 1 & $19,632.16$ & 10.45 & 0.0024 & \\
\hline Residual & $78,934.78$ & 42 & 1879.40 & & & \\
\hline Lack of Fit & $73,014.84$ & 35 & 2086.14 & 2.47 & 0.1075 & Not significant \\
\hline Pure Error & 5919.94 & 7 & 845.71 & & & \\
\hline \multicolumn{7}{|c|}{$\mathrm{R}^{2}=0.5698, \mathrm{R}^{2}$ adj $=0.4981, \mathrm{R}^{2}$ pred $=0.3063$, Adeq Precision $=10.3522$} \\
\hline \multicolumn{7}{|c|}{ S. squarrosum } \\
\hline Model & $81,613.04$ & 7 & $11,659.01$ & 8.69 & $<0.0001$ & Significant \\
\hline A-Sucrose & $42,609.81$ & 1 & $42,609.81$ & 31.74 & $<0.0001$ & \\
\hline B- $\mathrm{NH}_{4} \mathrm{NO}_{3}$ & $11,690.92$ & 1 & $11,690.92$ & 8.71 & 0.0052 & \\
\hline D-ME & 5871.59 & 1 & 5871.59 & 4.37 & 0.0426 & \\
\hline $\mathrm{E}-\mathrm{FeSO}_{4}$ & 5339.73 & 1 & 5339.73 & 3.98 & 0.0526 & \\
\hline $\mathrm{AB}$ & 7919.11 & 1 & 7919.11 & 5.90 & 0.0195 & \\
\hline $\mathrm{DE}$ & 4213.62 & 1 & 4213.62 & 3.14 & 0.0837 & \\
\hline $\mathrm{A}^{2}$ & 3968.26 & 1 & 3968.26 & 2.96 & 0.0929 & \\
\hline Residual & $56,377.14$ & 42 & 1342.31 & & & \\
\hline Lack of Fit & $48,734.03$ & 35 & 1392.40 & 1.28 & 0.3950 & Not significant \\
\hline Pure Error & 7643.11 & 7 & 1091.87 & & & \\
\hline \multicolumn{7}{|c|}{$\mathrm{R}^{2}=0.5914, \mathrm{R}^{2}$ adj $=0.5233, \mathrm{R}^{2}$ pred $=0.4260$, Adeq Precision $=11.9436$} \\
\hline
\end{tabular}




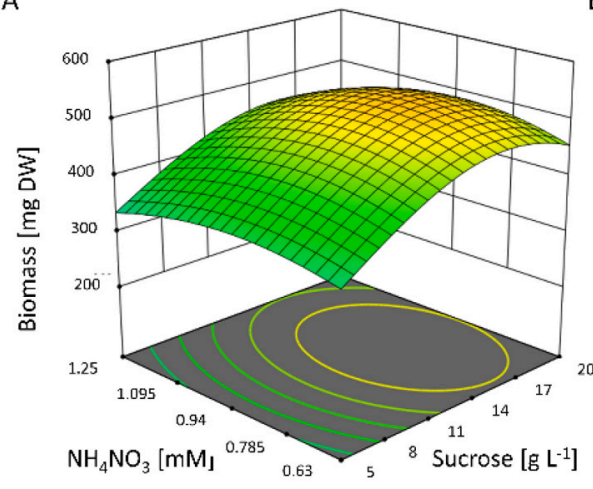

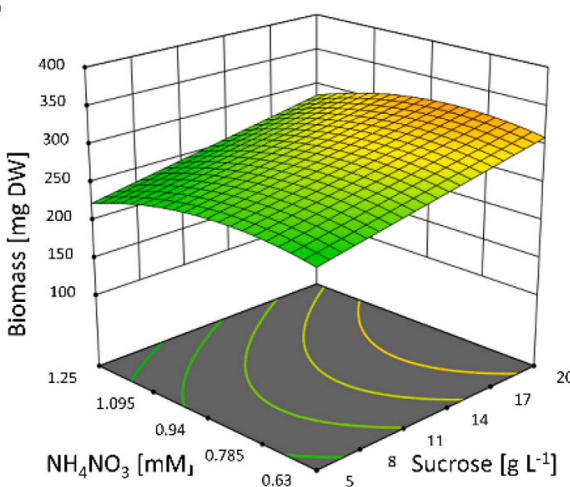

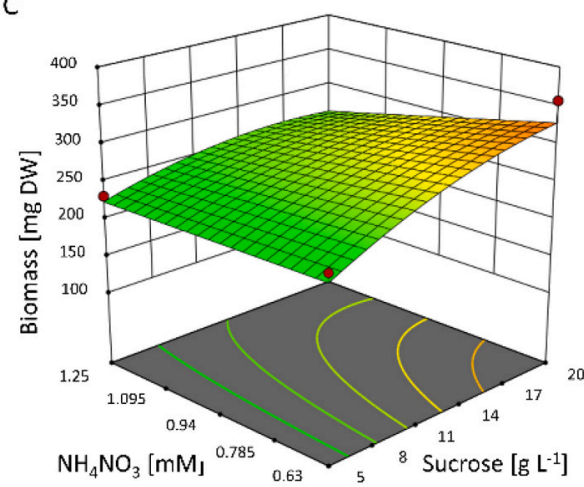

Fig. 1. 3D response surface for biomass production of $S$. fuscum, S. palustre and $S$. squarrosum. The plot shows the effect of interaction between $\mathrm{NH}_{4} \mathrm{NO}_{3}$ and sucrose of A) S. fuscum $\left(\mathrm{KH}_{2} \mathrm{PO}_{4}, \mathrm{Ca}\left(\mathrm{NO}_{3}\right)_{2}\right.$ and $\mathrm{ME}$ were kept konstant at $1.29 \mathrm{mM}, 2.12$. mM and 50\%, respectively), B) $S$. palustre $\left(\mathrm{KH}_{2} \mathrm{PO}_{4}, \mathrm{MgSO}_{4} \text { and Ca(NO} 3\right)_{2}$ were kept konstant at $0.92 \mathrm{mM}, 0.78 . \mathrm{mM}$ and $3.14 \mathrm{mM}$, respectively) and C) $S$. squarrosum $\left(\mathrm{Ca}\left(\mathrm{NO}_{3}\right)_{2}, \mathrm{ME}\right.$ and $\mathrm{FeSO}_{4}$ were kept konstant at $2.12 \mathrm{mM}, 50 \%$ and $22.5 \mu \mathrm{M}$, respectively).

Table 5

Optimized media composition of $S$. fuscum, $S$. palustre and $S$. squarrosum. The amount of nutrients in $100 \%$ of the standard Sphagnum medium is compared with the optimized fuscum, palustre and squarrosum media. The chemical formulas of hydrated salts are expressed without water molecules.

\begin{tabular}{lllll}
\hline & $\begin{array}{l}\text { Standard Sphagnum } \\
\text { medium (100\%) }\end{array}$ & S. fuscum & S. palustre & S. squarrosum \\
\hline Sucrose & $20\left(\mathrm{~g} \mathrm{~L}^{-1}\right)$ & $80 \%$ & $100 \%$ & $100 \%$ \\
$\mathrm{NH}_{4} \mathrm{NO}_{3}$ & $1.25(\mathrm{mM})$ & $71 \%$ & $68 \%$ & $50 \%$ \\
$\mathrm{KH}_{2} \mathrm{PO}_{4}$ & $1.84(\mathrm{mM})$ & $70 \%$ & $50 \%$ & $50 \%$ \\
$\mathrm{KCl}$ & $3.35(\mathrm{mM})$ & $50 \%$ & $50 \%$ & $50 \%$ \\
$\mathrm{MgSO}$ & $1.01(\mathrm{mM})$ & $50 \%$ & $77 \%$ & $50 \%$ \\
$\mathrm{Ca}$ & $4.24(\mathrm{mM})$ & $50 \%$ & $74 \%$ & $50 \%$ \\
$\quad\left(\mathrm{NO}_{3}\right)_{2}$ & & $50 \%$ & $50 \%$ & $50 \%$ \\
$\mathrm{ME}^{\mathrm{FeSO}}$ & $100 \%$ & $50 \%$ & $50 \%$ & $50 \%$ \\
\hline
\end{tabular}

stems and apical branches showed the highest regeneration potential for S. palustre, while brown parts and leaves did not regenerate (Sobotka, 2015), and the regeneration potential of $S$. angustifolium capitula was up to ten times higher than out of stems (Tuittila et al., 2003), which is in line with our own observations. The inocula may vary in the composition of parts of the gametophores and therefore may have a varying regeneration potential. The use of a defined number of capitula as inoculum may thus result in a more homogenous batch-to-batch productivity. However, such a labour-intensive procedure can be used for research especially in optimization studies, but it is not appropriate for the production of founder material for Sphagnum farming.

The concentrations of $\mathrm{KCl}, \mathrm{ME}$ and $\mathrm{FeSO}_{4}$ are set at $50 \%$ of the standard Sphagnum medium in the optimized media composition of $S$. fuscum, $S$. palustre and $S$. squarrosum, whereas the concentration of sucrose, $\mathrm{NH}_{4} \mathrm{NO}_{3}, \mathrm{KH}_{2} \mathrm{PO}_{4}, \mathrm{MgSO}_{4}$ and $\mathrm{Ca}\left(\mathrm{NO}_{3}\right)_{2}$ varies between all three species, which may reflect the nutrition status of their respective habitats. Although $S$. squarrsoum can be found in the most nutrient-rich locations, the optimized medium has the lowest nutrient concentrations with the exception of sucrose. S. palustre needed the same concentration of sucrose and the highest concentrations of $\mathrm{MgSO}_{4}$ and $\mathrm{Ca}\left(\mathrm{NO}_{3}\right)_{2}$ compared to the other two species. In contrast, the nutrient-poor adapted $S$. fuscum needed the lowest concentration of sucrose as well as the highest concentrations of $\mathrm{NH}_{4} \mathrm{NO}_{3}$ and $\mathrm{KH}_{2} \mathrm{PO}_{4}$. The phosphate mobility of oligotrophic raised-bog soils is higher than that of mineral soils (Kuntze and Scheffer, 1979), which could explain the higher consumption of $\mathrm{PO}_{4}^{3-}$.

Sucrose concentration played a significant role for peat moss productivity in all three optimized media. This is in agreement with the literature: The growth of $S$. nemoreum could be increased by addition of sucrose, glucose, fructose and mannose with 1\% sucrose as the best carbon source (Simola, 1969). Also in Beike et al. (2015), 2\% sucrose significantly increased the productivity of $S$. palustre compared to $0.3 \%$ sucrose. In contrast, $S$. imbricatum utilized glucose as the main carbon and energy source for their growth (Kajita et al., 1987).

Glucose and other sugars occur in the peat and peat water from decomposing organic matter, or are exuded from the roots of nearby vascular plants (Graham et al., 2010). The uptake of sugars (mixotrophy) helps peat mosses to deal with carbon limitations (Graham et al., 2010).

S. fuscum forms compact hummocks on raised or blanket mires, while S. palustre and $S$. squarrosum can be found in wet woodlands, ditches and flushes (Atherton et al., 2010). This correlates with the higher required amount of sucrose for the submerged species $S$. palustre and $S$. squarrosum as compared to the emergent species $S$. fuscum. However, at current knowledge an optimal medium composition in the laboratory can not be predicted from the knowledge of the natural habitat. Besides the multitude of inorganic salts and sugars described here, specific microbiome compositions in the natural habitat (e.g., Holland-Moritz et al., 2021) may explain different nutrient requirements between the field and the axenic laboratory culture.

\subsection{Verification of the optimized medium in the photobioreactor}

The optimization of media composition was validated on a larger scale in $5 \mathrm{~L}$ photobioreactors by comparing productivities in the standard and the optimized medium (Fig. 2).

The optimized medium of all three Sphagnum species increased productivity and these media needed less nutrients compared to the standard Sphagnum medium (Table 5), which is economically sensible. Nevertheless, S. squarrosum showed the lowest productivities in the bioreactor among the three species. This is in contrast to the axenic invitro cultivation in flasks, where $S$. squarrosum yielded the highest biomass compared to $S$. fuscum and $S$. palustre in the standard Sphagnum medium (Heck et al., 2021). One possible explanation for this discrepancy is the difference in the cultivation technology; rotating flasks versus stirred bioreactors. Consequently, experiments on shear-stress sensitivity of this peat moss species may show in future whether different hydrodynamic and mixing conditions in the bioreactor can impede the productivity of $S$. squarrosum.

Cultivation of about $15 \mathrm{~g}$ start FW in the photobioreactor containing $5 \mathrm{~L}$ of the respective optimized medium for 24 days resulted in $628.7 \pm$ $36.7 \mathrm{~g}$ FW of $S$. fuscum, $576.3 \pm 6.2 \mathrm{~g}$ FW of $S$. palustre and $398.5 \pm 31.8$ $\mathrm{g}$ FW of $S$. squarrosum with a fresh to dry weight ratio of $9.2 \pm 0.3$ ( $n=$ 9). This is in contrast to Beike et al. (2015), where the ratio of fresh to dry weight is approximately $14 \pm 2.7(n=12)$ for $S$. palustre. This 


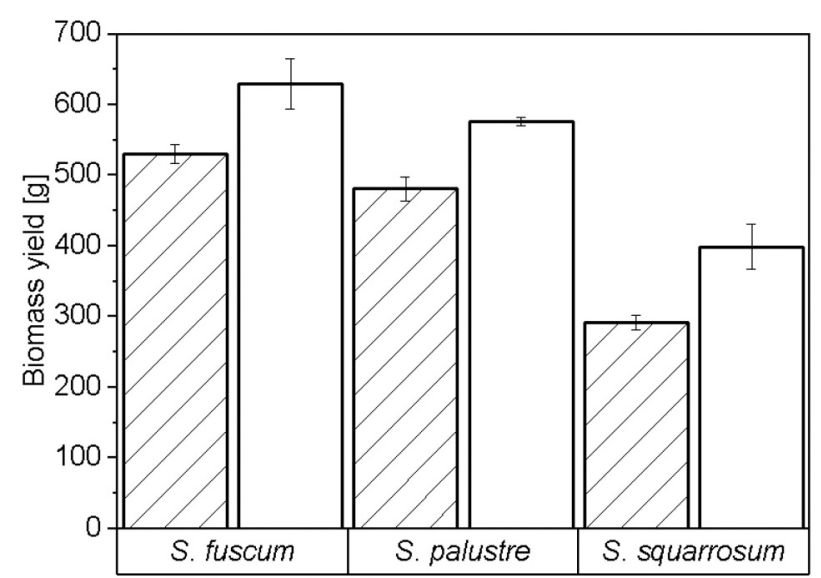

Fig. 2. Biomass yield of $S$. fuscum, $S$. palustre and $S$. squarrosum in 5 L photobioreactors. The Sphagnum species were cultivated for 24 days in (hatched bar) standard Sphagnum medium $(\mathrm{n}=2)$ and in (empty bar) optimized medium ( $=3$ ) including error bars (mean $\pm \mathrm{SD}$ ) to bioreactor runs.

variance is a consequence of the different methods of fresh weight determination. In both cases the moss material was filtered for $1 \mathrm{~min}$, but in this study, closing the funnel and generating a vacuum removes more water, which leads to a lower and less varying fresh to dry weight ratio.

Compared to the cultivation of $S$. palustre with a 30 -fold biomass increase in the photobioreactor of Beike et al. (2015), precultivation of the inocula and aeration of the bioreactor with $2 \% \mathrm{CO}_{2}$ shortened the cultivation time from about 30 days to 24 days with a similar biomass production of $54 \pm 2 \mathrm{~g}$ DW out of $1.8 \mathrm{~g}$ DW (30-fold increase) in our study. Optimization of the standard Sphagnum medium furthermore increased the biomass production to nearly 40 -fold in our study.

The optical assessment of biomass increase is depicted in Fig. 3A for S. fuscum, Fig. 4A for S. palustre and Fig. 5A for S. squarrosum. In the first week of cultivation the biomass amount in the bioreactor remained constant. This might be connected to the lag phase that Beike et al. (2015) reported. Visually, an increase in biomass was evident from the images taken on day 7. From day 13 to 17 , depending on the species, the bioreactor was filled with the produced biomass. There were still some free spaces inbetween the gametophores for growth, which were filled at the end of the cultivation. At first the moss was bright green and became darker and partly brownish towards the end (Figs. 3A, 4A, 5A), which seems to have no effect on the vitality of the moss. This color change may be due to high light availability. In nature, the majority of the species are green when shaded and develop secondary pigments when well-illuminated (Atherton et al., 2010). S. fuscum is found to be mid to deep brown and rarely all green. $S$. palustre is pale green or yellowbrown and occasionally the whole plant is green, whereas S. squarrosum varies from pale green to yellow-green and rarely pale brown (Daniels and Eddy, 1990).

The $\mathrm{pH}$ was not adjusted during cultivation according to the findings of Beike et al. (2015), a fixed pH was not suitable for the cultivation of $S$. palustre in the photobioreactor. We also observed the $\mathrm{pH}$ drop after autoclaving caused by precipitation of some nutrients (Beike et al., 2015). In addition, the inoculation with a two-week-old precultre decreased the starting $\mathrm{pH}$ further. The changes in $\mathrm{pH}$ during the bioreactor cultivation of all Sphagnum species was similar (Figs. 3B, 4B, 5B). After starting the cultivation, the $\mathrm{pH}$ decreased in the first three days from almost $\mathrm{pH} 4.4$ for $S$. fuscum and $S$. squarrosum and an initial $\mathrm{pH}$ of around 3.8 for $S$. palustre to nearly $\mathrm{pH}$ 3.1. This acidification is related to ion exchange, as cations were taken up by the surface of the plants, a phenomenon observed in nature (Clymo, 1963, 1964) as well as in invitro cultures (Beike et al., 2015; Rudolph et al., 1988). Especially ammonia uptake correlated with the $\mathrm{pH}$ decrease (Figs. 3F, 4F, 5F). After reaching the $\mathrm{pH}$ minimum, the whole amount of ammonia is taken up. This result is explained by the release of $\mathrm{H}^{+}$ions through the assmiliation of ammonium ions in the cytoplasm (Kirkby, 1968; Raven and Smith, 1976). During further cultivation, the $\mathrm{pH}$ increased again up to $\mathrm{pH} 5.3$ at day 14 for $S$. fuscum, up to $\mathrm{pH} 4.7$ between day 15 to 20 for S. palustre and up to $\mathrm{pH} 6.4$ between day 13 to 15 for $S$. squarrosum, accompanied by the uptake of nitrate ions. The assimilation of nitrate releases $\mathrm{OH}^{-}$ions. To keep the $\mathrm{pH}$ value constant in the cytoplasm, excess $\mathrm{OH}^{-}$is excreted from the cell (Raven and Smith, 1976). The complete uptake of nitrate (Figs. 3J, $4 \mathrm{~J}, 5 \mathrm{~J}$ ) is in correlation with the $\mathrm{pH}$ maxima (Figs. 3B, 4B, 5B). After the nitrate is taken up, the $\mathrm{pH}$ started to decrease again to nearly 3.7 for all tested species. It seems that nitrogen deprivation affects the $\mathrm{pH}$ value of the medium. Rasmussen et al. (1995) reported about excretion of Sphagnum acid into the culture media of S. fallax and S. cuspidatum. However, we could not find any reported correlation between nitrogen starvation and Sphagnum acid production.

The analysis of the nutrient concentrations in the medium revealed a rapid decrease of ammonia during the first three cultivation days (Figs. 3F, 4F, 5F), while nitrate was taken up more slowly (Figs. 3J, 4J, $5 \mathrm{~J})$. It is obvious that ammonia is the preferred nitrogen source in the three species tested here, which is in agreement with data about S. nemoreum (Simola, 1975).

During all bioreactor runs we observed that nitrate was completely depleted from the medium before the end of the experiment. Nevertheless, the results of DOE showed that higher concentration of nitrate did not lead to higher biomass yield. Higher light availabilty and additional $\mathrm{CO}_{2}$ supplementation in bioreactor cultures increase the photosynthetic acivity of Sphagnum (Haraguchi and Yamada, 2011; Jauhiainen and Silvola, 1999). This could result in better growth responses with higher nutrient requirements compared to flask cultivation, which were conducted without supplementation of $\mathrm{CO}_{2}$.

The optimized media contained $1.6 \%$ sucrose for $S$. fuscum and $2 \%$ sucrose for $S$. palustre and $S$. squarrosum. Besides sucrose, glucose and fructose could be detected right at the beginning of the cultivation (Figs. 3, 4, 5 (C D E)). The disaccharide sucrose partially hydrolysed to its monosaccharides glucose and fructose due to high temperature during autoclaving as reported before (Ball, 1953).

The initial sugar concentration was higher than expected for S. palustre and S. squarrosum. During the hydrolysis of sucrose a water molecule is added, which results in a $5 \%$ higher molecular weight of the monosaccharides (glucose/fructose $180.16 \mathrm{~g} \mathrm{~mol}^{-1}$ ) compared to the disaccharide (sucrose $342.30 \mathrm{~g} \mathrm{~mol}^{-1}$ ). Due to the low standard deviation of the sugar measurements, another reason for the concentration difference could be the preculture medium still containing not completely utilized sugars, which would increase the available amount at the beginning of the bioreactor cultivation. The growth of the preculture seems to be slower compared to the bioreactor culture due to different aeration without $\mathrm{CO}_{2}$ supplementation, different light sources resulting in different light spectra and lower light availibilty. On the other hand, it is reported that light intensity had no influence on the growth of several moss species in organic nutrient medium (Fries, 1945) and on the growth of $S$. nemoreum in the presence of exogenous sugars, but the light quality and quantity used was certainly not the same (Simola, 1969).

For the initial high sucrose content it is also possible that the sugar assay is not absolutely specific for sucrose, as $\beta$-fructosidase also hydrolyses low molecular weight fructans (Megazyme Booklet), which could increase the amount of the measured sucrose. Sucrose and fructan are the major soluble carbohydrates of Sphagnum (Maass and Craigie, 1964; Marschall and Laufer, 2002). The secretion of fructan by peat mosses has not been reported yet, but they contribute to the total dissolved organic carbon of peat leachate (Fenner et al., 2004).

Further analysis of sugar concentrations in our cultivation media showed that during 10 to 13 days of cultivation of $S$. palustre and $S$. fuscum, nearly all sucrose was depleted from the medium, whereas the concentrations of glucose and fructose increased during that time. The 
A
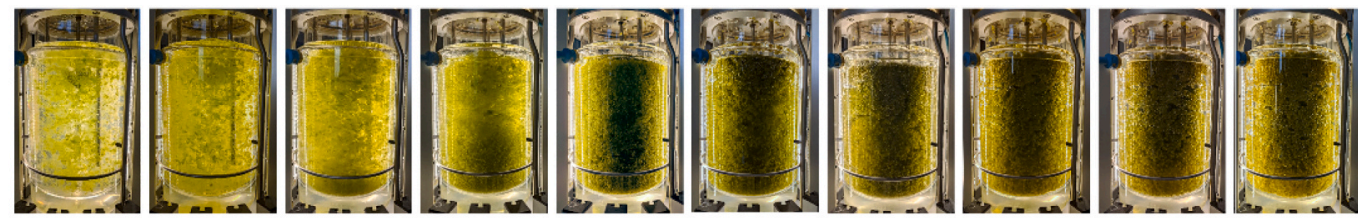

day 0 day 3

day 7

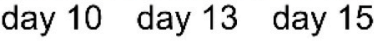

day 17

day 22 day 24
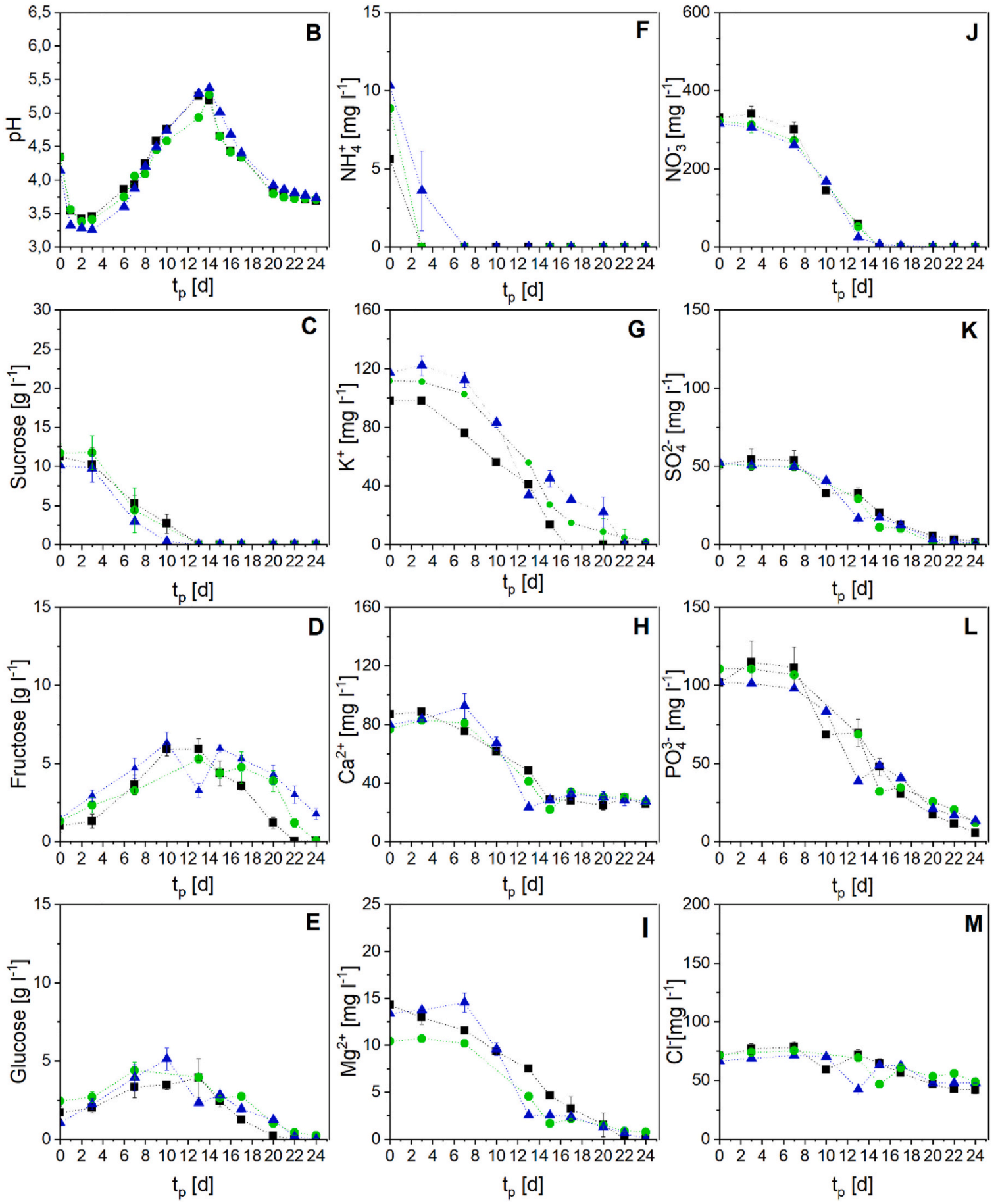

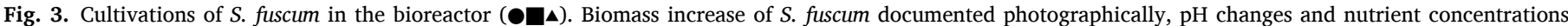

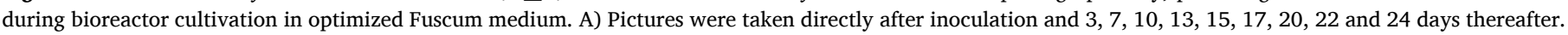

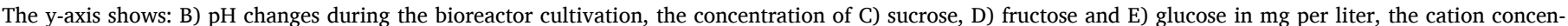

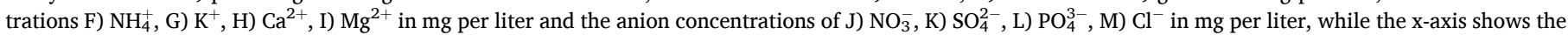
day of cultivation. Error bars (mean $\pm \mathrm{SD}$ ) to three independent mesauerment of the nutrient sample. 
A

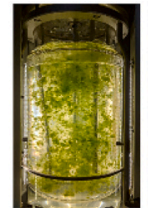

day 0

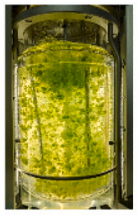

day 3

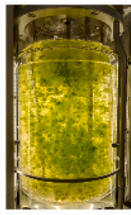

day 7

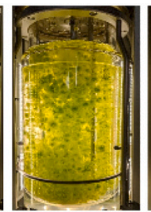

day 10

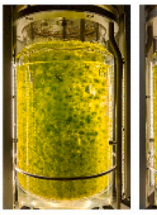

day 13 day 15

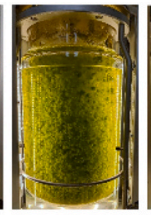

day 17

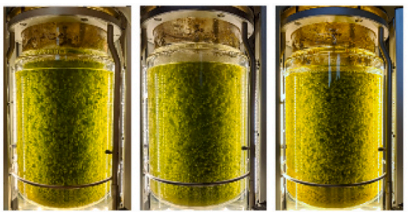

day 20 day 22 day 24
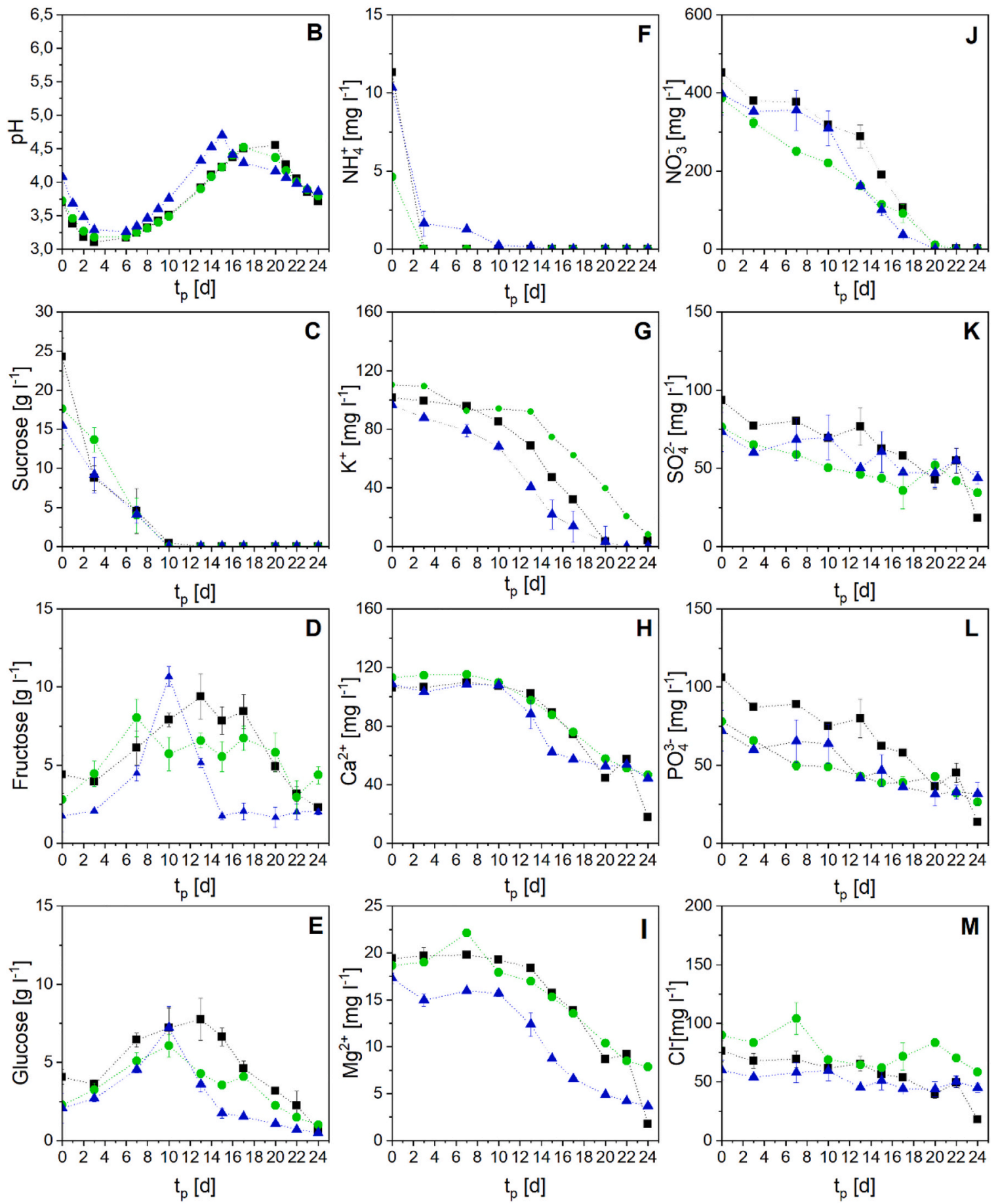

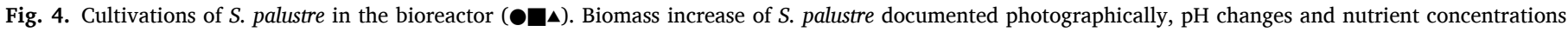

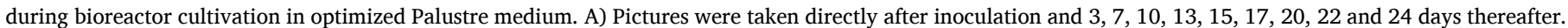

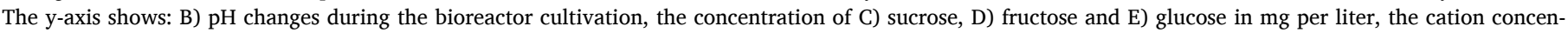

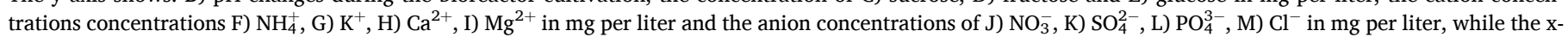
axis shows the day of cultivation. Error bars (mean $\pm \mathrm{SD}$ ) to three independent mesauerment of the nutrient sample. 
A

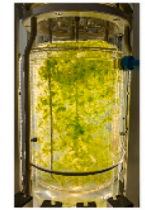

day 0

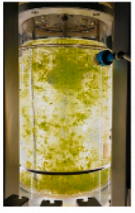

day 3

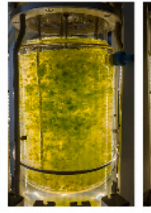

day 7

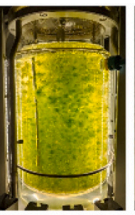

day 10

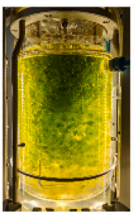

day 13

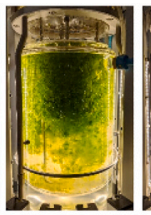

day 15

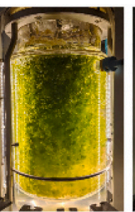

day 17

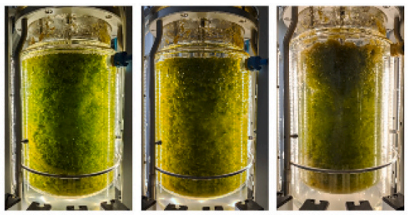

day 22 day 24
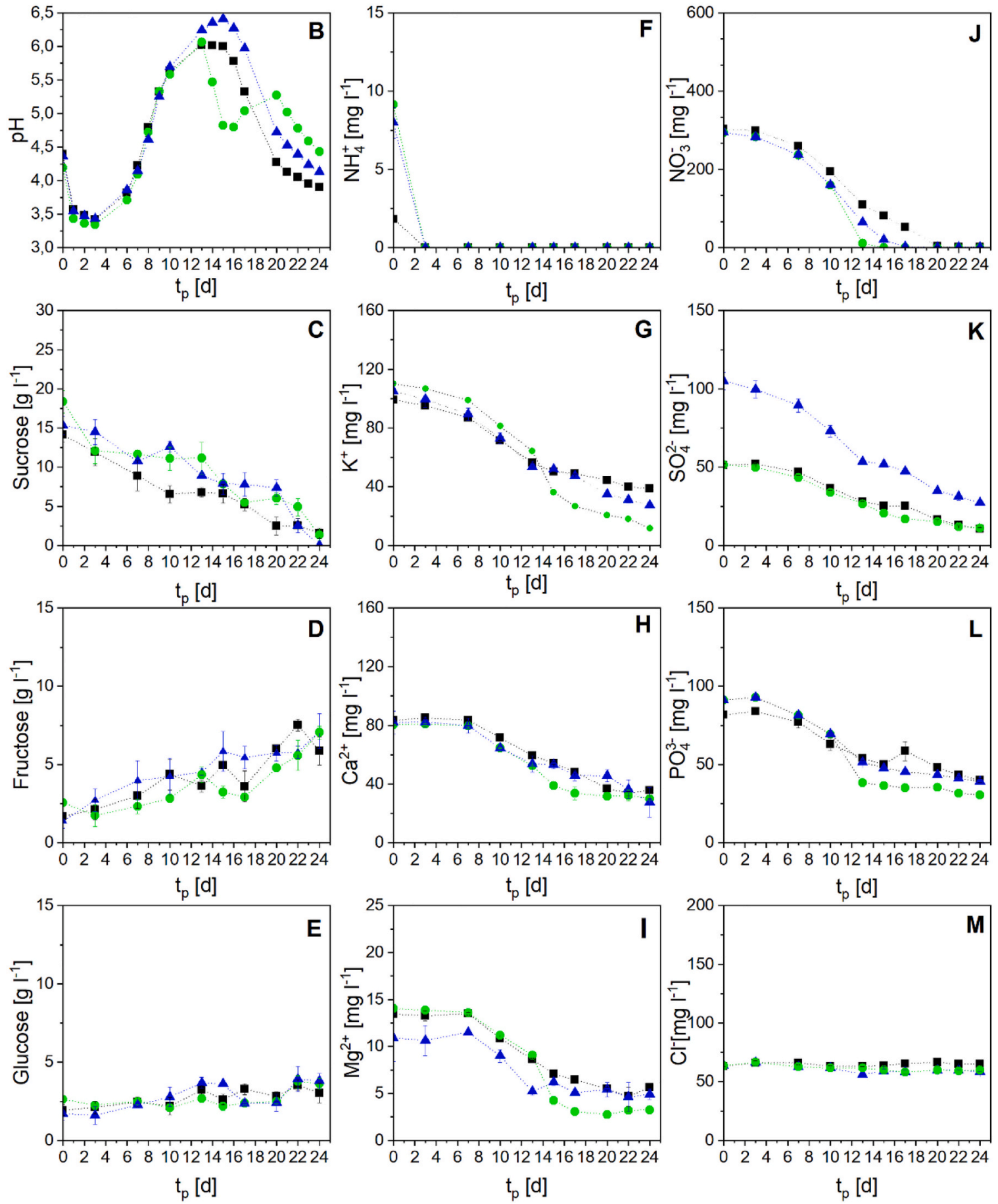

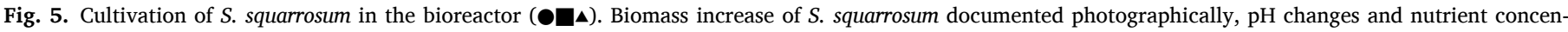

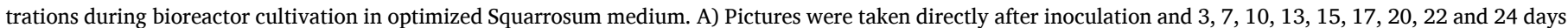

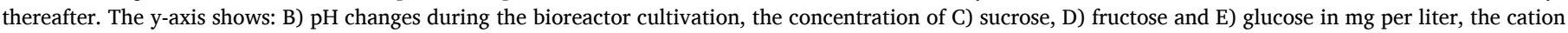

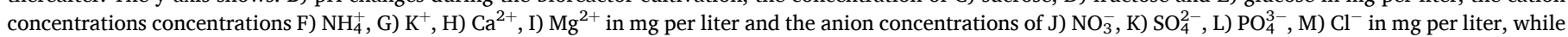
the $\mathrm{x}$-axis shows the day of cultivation. Error bars (mean \pm SD) to three independent mesauerment of the nutrient sample. 
pH courses (Figs. 3B, 4B, 5B) indicate that hydrolysis did not occur due to acidification of the medium, because the $\mathrm{pH}$ minimum was reached at day 3 of cultivation, while the sucrose was depleted approximately on day 10 , dependent on the species. We suppose that most of the sucrose is hydrolysed by enzymes secreted by the mosses. In accordance with this are reports on sucrose cleavage by cell wall acid-type invertases in S. nemoreum (Simola, 1969), in S. recurvum (Marschall and Laufer, 2002) and in S. compactum (Graham et al., 2010). Comparing the sucrose concentration during the first three days of cultivation of $S$. squarrosum with $S$. fuscum suggests that $S$. squarrosum is capable of cleaving less sucrose compared to $S$. fuscum under the same $\mathrm{pH}$ changes. This could be the result of different enzyme activities of invertases among the species. Future analyses may reveal whether the moss species differ in the enzyme activities of acid-invertases or in enzyme amounts in the cell wall.

After the absence of detectable sucrose, glucose and fructose concentrations were decreasing until both sugars were consumed. We observed that the total consumption of fructose took place two days later compared to glucose in $S$. palustre's cultivation. At the end of $S$. fuscum's cultivation, glucose was nearly depleted and up to $2 \mathrm{~g} \mathrm{~L}^{-1}$ of fructose remained. The ablity to take up exogenuous sugars is well known for Sphagnum mosses (Simola, 1969; Graham et al., 2010). Glucose and fructose can be absorbed via monossacharide transporters and utilized for growth and energy (Simola, 1969). Graham et al. (2010) showed that glucose is preferentially taken up by Sphagnum mosses, which correlates with the findings in our study, because glucose was absorbed more quickly than fructose.

Our results also show that $S$. squarrosum hydrolyzed the sucrose slower than both other species in the beginning of the cultivation (Fig. 5C) and some sucrose was still left in the medium at the end of the cultivation (Fig. 5C). Apart from the possible lower enzyme activity of acid-invertase in this species, the overreaching of $\mathrm{pH} 5.5$ may also affect the hydrolysis. Due to the fact that the invertase enzymes have their optimum activity at pH values between 4.0 and 5.5 (Chibbar et al., 2016), the sucrose hydrolysis could be partially slowed down with increasing $\mathrm{pH}$. This could have slowed down the growth of $S$. squarrosum. On the other hand, $S$. squarrosum is able to tolerate baserich water (Daniels and Eddy, 1990) and is less sensitive to higher $\mathrm{pH}$ than S. palustre is (Clymo, 1973; Harpenslager et al., 2015).

As sucrose is not completely utilized, but has a positive effect on the growth of $S$. squarrosum, the presence of sucrose might have an indirect effect on the growth. Sugars are not only important in plant energy metabolism, they are also important signal molecules that interact with several hormones and serve as morphogens (Rolland et al., 2002). Furthermore, the vacuolar osmotic potential is altered by polymerization or breakdown of fructan and this may alter turgor pressure (Marschall, 2010), which may improve the nutrient uptake. Such questions may be resolved in future studies using transcriptome profiling, as has been demonstrated for seed plants (e.g., Wang et al., 2018).

\section{Conclusion}

The major aim of this study was to optimize culture media for increased biomass productivity of three Sphagnum species. The media optimization allowed us to lower nutrient concentrations while increasing productivity. This made the production process economically favorable for large scale biomass production used as founder material for Sphagnum farming. As there is no correlation between the optimal medium composition and nutrient requirements of the three tested Sphagnum species in their natural habitats, predictions for other Sphagnum species are not possible. Nevertheless, reducing the amount of nutrients to $50 \%$ of the hitherto used Sphagnum medium seems to be preferable.

\section{CRediT authorship contribution statement}

Melanie A. Heck: Investigation, Methodology, Validation, Formal analysis, Writing - original draft. Ingrida Melková: Investigation, Methodology, Writing - review \& editing. Clemens Posten: Supervision, Writing - review \& editing, Funding acquisition. Eva L. Decker: Conceptualization, Supervision, Writing - review \& editing. Ralf Reski: Supervision, Writing - review \& editing, Funding acquisition.

\section{Declaration of competing interest}

The authors declare that they have no known competing financial interests or personal relationships that could have appeared to influence the work reported in this paper.

\section{Acknowledgements}

This work was funded by the Federal Ministry of Food and Agriculture (BMEL) (MOOSzucht, No. 22007216/22007316 to R.R. and C.P.). Additional support came from the German Research Foundation (DFG) under Germany's Excellence Strategy (CIBSS - EXC-2189 - Project ID 390939984 and livMatS - EXC-2193 to R.R.). We gratefully acknowledge Anja Kuberski for technical assistance, Olga Gorte and Christin Kubisch for performing HPLC measurements and Anne Katrin Prowse for proofreading of the manuscript.

\section{Appendix A. Supplementary data}

Supplementary data to this article can be found online at https://doi. org/10.1016/j.biteb.2021.100729.

\section{References}

Aboal, J.R., Concha-Graña, E., De Nicola, F., Muniategui-Lorenzo, S., López-Mahía, P., Giordano, S., Capozzi, F., Di Palma, A., Reski, R., Zechmeister, H., MartínezAbaigar, J., Fernández, J.A., 2020. Testing a novel biotechnological passive sampler for monitoring atmospheric PAH pollution. J. Hazard. Mater. 381, 120949.

Atherton, I., Bosanquet, S.D.S., Lawley, M., British Bryological Society, 2010. Mosses and Liverworts of Britain and Ireland: A Field Guide, 1st ed. British Bryological Society, Middlewich.

Ball, E., 1953. Hydrolysis of sucrose by autoclaving media, a neglected aspect in the technique of culture of plant tissues. Bull. Torrey Bot. Club 80, 409-411.

Beike, A.K., Spagnuolo, V., Lüth, V., Steinhart, F., Ramos-Gómez, J., Krebs, M., Adamo, P., Rey-Asensio, A.I., Fernández, J.A., Giordano, S., Decker, E.L., Reski, R., 2015. Clonal in vitro propagation of peat mosses Sphagnum L. as novel green resources for basic and applied research. Plant Cell Tissue Organ Cult. PCTOC 120, 1037-1049.

Bezerra, M.A., Santelli, R.E., Oliveira, E.P., Villar, L.S., Escaleira, L.A., 2008. Response surface methodology (RSM) as a tool for optimization in analytical chemistry. Talanta 76, 965-977.

Burnett, S.E., Mattson, N.S., Williams, K.A., 2016. Substrates and fertilizers for organic container production of herbs, vegetables, and herbaceous ornamental plants grown in greenhouses in the United States. Sci. Horticult. 208, 111-119.

Candioti, V.L., De Zan, M.M., Cámara, M.S., Goicoechea, H.C., 2014. Experimental design and multiple response optimization. Using the desirability function in analytical methods development. Talanta 124, 123-138.

Capozzi, F., Adamo, P., Di Palma, A., Aboal, J.R., Bargagli, R., Fernandez, J.A., Lopez Mahia, P., Reski, R., Tretiach, M., Spagnuolo, V., Giordano, S., 2017. Sphagnum palustre clone vs native Pseudoscleropodium purum: a first trial in the field to validate the future of the moss bag technique. Environ. Pollut. 225, 323-328.

Carlson, K.M., Gerber, J.S., Mueller, N.D., Herrero, M., MacDonald, G.K., Brauman, K.A., Havlik, P., O'Connell, C.S., Johnson, J.A., Saatchi, S., West, P.C., 2017. Greenhouse gas emissions intensity of global croplands. Nat. Clim. Chang. 7, 63-68.

Chibbar, R.N., Jaiswal, S., Gangola, M., Båga, M., 2016. Carbohydrate metabolism. In: Encyclopedia of Food Grains. Elsevier, pp. 161-173.

Clymo, R.S., 1963. Ion exchange in Sphagnum and its relation to bog ecology. Ann. Bot. 27, 309-324.

Clymo, R.S., 1964. The origin of acidity in Sphagnum bogs. Bryologist 67, 427-431.

Clymo, R.S., 1973. The growth of Sphagnum: some effects of environment. J. Ecol. 61, 849-869.

Daniels, R.E., Eddy, A., 1990. Handbook of European Sphagna. HMSO, London.

Di Palma, A., González, A.G., Adamo, P., Giordano, S., Reski, R., Pokrovsky, O.S., 2019. Biosurface properties and lead adsorption in a clone of Sphagnum palustre (Mosses): towards a unified protocol of biomonitoring of airborne heavy metal pollution. Chemosphere 236, 124375. 
Duraković, B., 2017. Design of experiments application, concepts, examples: state of the art. Period. Eng. Nat. Sci. PEN 5, 421-439.

Fenner, N., Ostle, N., Freeman, C., Sleep, D., Reynolds, B., 2004. Peatland carbon efflux partitioning reveals that Sphagnum photosynthate contributes to the DOC pool. Plant Soil 259, 345-354.

Fries, N., 1945. Some experiments with mosses cultured in the dark. Bot. Notiser 98 417-424.

Fukuda, I.M., Pinto, C.F.F., Moreira, C. dos S., Saviano, A.M., Lourenço, F.R., 2018. Design of Experiments (DoE) applied to pharmaceutical and analytical Quality by Design (QbD). Braz. J. Pharm. Sci. 54.

Gaudig, G., Fengler, F., Krebs, M., Prager, A., Schulz, J., Wichmann, S., Joosten, H., 2014 Sphagnum farming in Germany - a review of progress. Mires Peat 13, 08.

Gaudig, G., Krebs, M., Prager, A., Wichmann, S., 2018. Sphagnum farming from species selection to the production of growing media: a review. Mires Peat 20, 13.

Graham, L.E., Kim, E., Arancibia-Avila, P., Graham, J.M., Wilcox, L.W., 2010. Evolutionary and ecophysiological significance of sugar utilization by the peat moss Sphagnum compactum (Sphagnaceae) and the common charophycean associates Cylindrocystis brebissonii and Mougeotia sp. (Zygnemataceae). Am. J. Bot 97, 1485-1491.

Haraguchi, A., Yamada, N., 2011. Temperature dependency of photosynthesis of Sphagnum spp. distributed in the warm-temperate and the cool-temperate mires of Japan. Am. J. Plant Sci. 2, 716-725.

Harpenslager, S.F., van den Elzen, E., Kox, M.A.R., Smolders, A.J.P., Ettwig, K.F., Lamers, L.P.M., 2015. Rewetting former agricultural peatlands: Topsoil removal as a prerequisite to avoid strong nutrient and greenhouse gas emissions. Ecol. Eng. 84, 159-168.

Heck, M.A., Lüth, V.M., Gessel, N., Krebs, M., Kohl, M., Prager, A., Joosten, H., Decker, E. L., Reski, R., 2021. Axenic in vitro cultivation of 19 peat moss (Sphagnum L.) species as a resource for basic biology, biotechnology, and paludiculture. New Phytol. 229, 861-876.

Holland-Moritz, H., Stuart, J.E.M., Lewis, L.R., Miller, S.N., Mack, M.C., Ponciano, J.M., McDaniel, S.F., Fierer, N., 2021. The bacterial communities of Alaskan mosses and their contributions to $\mathrm{N}_{2}$-fixation. Microbiome 9, 53.

Jauhiainen, J., Silvola, J., 1999. Photosynthesis of Sphagnum fuscum at long-term raised $\mathrm{CO}_{2}$ concentrations. In: Ann. Bot. Fennici, vol. 36, pp. 11-19.

Joosten, H., Sirin, A., Couwenberg, J., Laine, J., Smith, P., 2016. The role of peatlands in climate regulation. In: Bonn, A., Allott, T., Evans, M., Joosten, H., Stoneman, R. (Eds.), Peatland Restoration and Ecosystem Services. Cambridge University Press, Cambridge, pp. 63-76.

Kajita, M., Takio, S., Takami, S., Hino, S., 1987. Establishment and growth characterization of suspension culture of cells from the moss, Sphagnum imbrication. Physiol. Plant. 70, 21-26.

Kirkby, E.A., 1968. Influence of ammonium and nitrate nutrition on the cation-anion balance and nitrogen and carbohydrate metabolism of white mustard plants grown in dilute nutrient solutions. Soil Sci. 105, 133-140.

Kuntze, H., Scheffer, B., 1979. Die Phosphatmobilität im Hochmoorboden in Abhängigkeit von der Düngung. Z. Für Pflanzenernähr. Bodenkd. 142, 155-168.

Maass, W., Craigie, J., 1964. Examination of some soluble constituents of Sphagnum gametophytes. Can. J. Bot. 42, 805-813.

Maina, S., Stylianou, E., Vogiatzi, E., Vlysidis, A., Mallouchos, A., Nychas, G.J.E., de Castro, A.M., Dheskali, E., Kookos, I.K., Koutinas, A., 2019. Improvement on bioprocess economics for 2,3-butanediol production from very high polarity cane sugar via optimisation of bioreactor operation. Bioresour. Technol. 274, 343-352.

Marschall, M., 2010. Photosynthetic responses, carbohydrate composition and invertase activity in fructan accumulating bryophytes (Porella platyphylla and Sphagnum flexuosum) under different environmental conditions (carbohydrate treatments, dark starvation, low temperature, desiccation). Acta Biol. Hung. 61, 120-129.

Marschall, M., Laufer, Z., 2002. Metabolic activity of Sphagnum recurvum under different environmental conditions. Acta Biol. Szeged. 46, 247-248. http://abs.bibl.u-szeged. hu/index.php/abs/article/view/2316.
Niedz, R.P., Evens, T.J., 2006. A solution to the problem of ion confounding in experimental biology. Nat. Methods 3, 417.

Poschlod, P., Pfadenhauer, J., 1989. Regeneration vegetativer Sprossteilchen von Torfmoosen. Eine vergleichende Studie an neun Sphagnum-Arten. Telma Berichte Dtsch. Ges. Fuer Moor- Torfkunde Hann. 19, 77-88.

Rasmussen, S., Wolff, C., Rudolph, H., 1995. Compartmentalization of phenolic constituents in. Sphagnum. Phytochemistry 38, 35-39.

Raven, J.A., Smith, F.A., 1976. Nitrogen assimilation and transport in vascular land plants in relation to intracellular $\mathrm{pH}$ regulation. New Phytol. 76, 415-431.

Rensing, S.A., Lang, D., Zimmer, A.D., Terry, A., Salamov, A., Shapiro, H., Nishiyama, T., Perroud, P.-F., Lindquist, E.A., Kamisugi, Y., Tanahashi, T., Sakakibara, K., Fujita, T., Oishi, K., Shin-I, T., Kuroki, Y., Toyoda, A., Suzuki, Y., Hashimoto, S., Yamaguchi, K., Sugano, S., Kohara, Y., Fujiyama, A., Anterola, A., Aoki, S., Ashton, N., Barbazuk, W. B., Barker, E., Bennetzen, J.L., Blankenship, R., Cho, S.H., Dutcher, S.K., Estelle, M., Fawcett, J.A., Gundlach, H., Hanada, K., Heyl, A., Hicks, K.A., Hughes, J., Lohr, M., Mayer, K., Melkozernov, A., Murata, T., Nelson, D.R., Pils, B., Prigge, M., Reiss, B., Renner, T., Rombauts, S., Rushton, P.J., Sanderfoot, A., Schween, G., Shiu, S.-H., Stueber, K., Theodoulou, F.L., Tu, H., Van de Peer, Y., Verrier, P.J., Waters, E., Wood, A., Yang, L., Cove, D., Cuming, A.C., Hasebe, M., Lucas, S., Mishler, B.D., Reski, R., Grigoriev, I.V., Quatrano, R.S., Boore, J.L., 2008. The Physcomitrella genome reveals evolutionary insights into the conquest of land by plants. Science 319, 64-69.

Reski, R., Abel, W.O., 1985. Induction of budding on chloronemata and caulonemata of the moss, Physcomitrella patens, using isopentenyladenine. Planta 165, 354-358.

Rolland, F., Moore, B., Sheen, J., 2002. Sugar sensing and signaling in plants. Plant Cell $14,185-205$.

Rudolph, H., Kirchhoff, M., Gliesmann, S., 1988. Sphagnum culture techniques. In: Glime, J.M. (Ed.), Methods in Bryology. Proc. Bryol. Meth. Workshop, Mainz. Hattori Bot. Lab., Nichinan, pp. 25-34.

Sabovljević, M.S., Sabovljević, A.D., Ikram, N.K.K., Peramuna, A., Bae, H., Simonsen, H. T., 2016. Bryophytes - an emerging source for herbal remedies and chemical production. Plant Genet. Resour. 14, 314-327.

Schween, G., Hohe, A., Koprivova, R., Reski, R., 2003. Effects of nutrients, cell density and culture techniques on protoplast regeneration and early protonema development in a moss, Physcomitrella patens. J. Plant Physiol. 160, 209-212.

Simola, L.K., 1969. The effect of various mono- and disaccharides on the growth of Sphagnum nemoreum thalli in sterile cultures. Physiol. Plant. 22, 1079-1084.

Simola, L.K., 1975. The effect of several protein amino acids and some inorganic nitrogen sources on the growth of Sphagnum nemoreum. Physiol. Plant. 35, 194-199.

Singh, V., Haque, S., Niwas, R., Srivastava, A., Pasupuleti, M., Tripathi, C.K.M., 2017. Strategies for fermentation medium optimization: an in-depth review. Front. Microbiol. 7, 2087.

Sobotka, D., 2015. Regeneration and vegetative propagation of Sphagnum palustre as factor of population stability. Acta Soc. Bot. Pol. 45, 357-368.

Tuittila, E.-S., Vasander, H., Laine, J., 2003. Success of re-introduced Sphagnum in a cutaway peatland. Boreal Environ. Res. 8, 245-250.

Turetsky, M.R., Benscoter, B., Page, S., Rein, G., van der Werf, G.R., Watts, A., 2015. Global vulnerability of peatlands to fire and carbon loss. Nat. Geosci. 8, 11-14.

Wang, K., Bai, Z.Y., Liang, Q.Y., Liu, Q.L., Zhang, L., Pan, Y.Z., Liu, G.L., Jiang, B.B., Zhang, F., Jia, Y., 2018. Transcriptome analysis of chrysanthemum (Dendranthema grandiflorum) in response to temperature stress. BMC Genomics 19, 319.

Weston, D.J., Turetsky, M.R., Johnson, M.G., Granath, G., Lindo, Z., Belyea, L.R., Rice, S. K., Hanson, D.T., Engelhardt, K.A.M., Schmutz, J., Dorrepaal, E., Euskirchen, E.S., Stenøien, H.K., Szövényi, P., Jackson, M., Piatkowski, B.T., Muchero, W., Norby, R. J., Kostka, J.E., Glass, J.B., Rydin, H., Limpens, J., Tuittila, E.-S., Ullrich, K.K., Carrell, A., Benscoter, B.W., Chen, J.-G., Oke, T.A., Nilsson, M.B., Ranjan, P., Jacobson, D., Lilleskov, E.A., Clymo, R.S., Shaw, A.J., 2018. The Sphagnome Project: enabling ecological and evolutionary insights through a genus-level sequencing project. New Phytol. 217, 16-25. 